\title{
BOREHOLE AND GEOHYDROLOGIC DATA FOR TEST \\ HOLE USW UZ-6, YUCCA MOUNTAIN AREA, NYE COUNTY, NEVADA
}

\author{
By Merrick S. Whitfield, Jr., U. S. Geological Survey; \\ Colleen M. Cope, Foothill Engineering Consultants, Inc.; and \\ Carole L. Loskot, U.S. Geological Survey
}

U.S. GEOLOGICAL SURVEY

Open-File Report 92-28

Prepared in cooperation with the

U.S. DEPARMENT OF ENERGY,

NEVADA FIEID OFFICE, under

Interagency Agreement DE-AI08-78ET44802

\section{DISCLAIMER}

This report was prepared as an account of work sponsored by an agency of the United States Government. Neither the United States Government nor any agency thereof, nor any of their employees, makes any warranty, express or implied, or assumes any legal liability or responsibility for the accuracy, completeness, or usefulness of any information, apparatus, product, or process disclosed, or represents that its use would not infringe privately owned rights. Reference herein to any specific commercial product, process, or service by trade name, trademark, manufacturer, or otherwise does not necessarily constitute or imply its endorsement, recommendation, or favoring by the United States Government or any agency thereof. The views and opinions of authors expressed herein do not necessarily state or reflect those of the United States Government or any agency thereof.

Denver, Colorado

1993
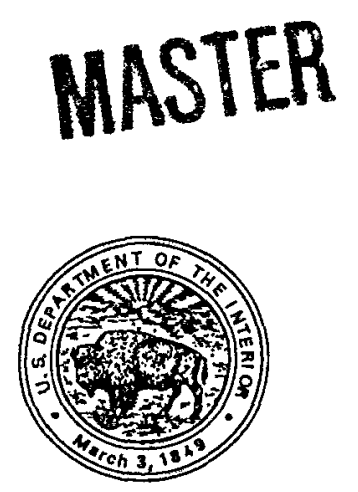


\section{U.S. DEPARTMENT OF THE INTERIOR BRUCE BABBITT, Secretary \\ U.S. GEOLOGICAL SURVEY \\ Dallas L. Peck, Director}

For additional information write to:

Chief, Hydrologic Project Branch Program

Yucca Mountain Project Branch

U.S. Geological Survey

Box 25046, Mail Stop 421

Federal Center

Denver, Co 80225-0046
Copies of this report can

be purchased from:

U.S. Geological Survey

Books and Open-File Reports Section Federal Center

Box 25425

Denver, CO 80225 


\section{DISCLAIMER}

\section{Portions of this document may be illegible in electronic image products. Images are produced from the best available original document.}


Abstract-1.- Page

Introduction-0-1

Borehole data--

Drilling procedures-- 4

Borehole construction and geologic units penetrated-_- 6

Geohydrologic data-- 6

Drill-bit cuttings-an 6

Collection and processing- 6

Lithology of geologic units penetrated-_an 11

Gravimetric water-content measurements-_- 17

Water-potential measurements- 27

Geophysical logs and television videotapes-_. 32

Summary--

References cited-1. 35

FIGURES

Figure 1. Map showing location of test holes USW UZ-1, USW UZ-6, and USW UZ-6s, and nearby geographic features in southern Nevada-- 3

2-4. Schematic diagrams showing:

2. Drill rig, separators, vacuum unit, and exhaust muffler for the vacuum reverse-air-circulation method of dry drilling 5

3. Borehole construction- 7

4. Borehole deviation survey- 8

5-9. Graphs showing:

5. Drilling rate and geologic units penetrated in test hole USW UZ-6- 9

6. Generalized distribution of welding in geologic units penetrated by test hole USW UZ-6-_ 10

7. Gravimetric water-content measurements of drill-bit cuttings from test hole USW UZ-6 25

8. Water-potential measurements of drill-bit cuttings

9. Vertical distribution and number of fractures in test hole USW UZ-6-6

\section{TABLES}

Table, 1. Lithologic log of drill-bit cuttings from test hole USW UZ-6-

Page

2. Results of laboratory analyses for gravimetric watercontent and water-potential measurements of drill-bit cuttings from test hole USW UZ-6- 
Table 3. Summary of gravimetric water-content measurements of drillbit cuttings for test hole USW UZ-6, related to lithology and degree of welding

4. Comparison of gravimetric water-content measurements of drill-bit cuttings from test holes USW UZ-6 and USW UZ-6s by geologic unit-

5. Summary of water-potential measurements of drill-bit cuttings for test hole USW UZ-6, related to lithology and degree of welding

6. Summary of geophysical logs and television videotapes obtained in test hole USW UZ-6

\section{CONVERSION FACTORS, ABBREVIATED WATER-QUALITY}

TERM, AND VERTICAL DATUM

\begin{tabular}{lll} 
Multiply & \multicolumn{1}{c}{$B g$} & To obtain \\
centimeter $(\mathrm{cm})$ & 0.3937 & inch \\
cubic centimeter per minute & 0.3937 & inch per minute \\
$\quad\left(\mathrm{cm}^{3} / \mathrm{min}\right)$ & 0.6214 & mile \\
kilometer $(\mathrm{km})$ & 0.1450 & pound per square inch \\
kilopascal (kPa) & 0.01 & bar (14.5 pounds per \\
kilopascal (kPa) & & square inch) \\
liter (L) & 1.057 & quart \\
meter (m) & 3.281 & foot \\
milliliter $(\mathrm{mL})$ & 0.0612 & inch cubed \\
millimeter (mm) & 0.03937 & inch
\end{tabular}

Temperatures are given in degree Celsius. To convert degree Celsius $\left({ }^{\circ} \mathrm{C}\right)$ to degree Fahrenheit $\left({ }^{\circ} \mathrm{F}\right)$ use the following formula:

$$
{ }^{\circ} \mathrm{F}=9 / 5\left({ }^{\circ} \mathrm{C}\right)+32 .
$$

The following terms and abbreviations also are used in this report:

$$
\begin{gathered}
\text { gram per gram }(g / g) \\
\text { molality }(m)
\end{gathered}
$$

Sea Level: In this report, "sea level" refers to the National Geodetic Vertical Datum of 1929 (NGVD of 1929)--a geodetic datum derived from a general adjustment of the first-order level nets of both the United States and Canada, formerly called "Sea Level Datum of 1929." 


\title{
BOREHOLE AND GEOHYDROLOGIC DATA FOR TEST HOLE USW UZ-6,
} YUCCA MOUNTAIN AREA, NYE COUNTY, NEVADA

By Merrick S. Whitfield, Jr. ${ }^{1}$, Colleen M. Cope ${ }^{2}$, and Carole L. Loskot ${ }^{1}$

\begin{abstract}
Test hole USW UZ-6, located 1.8 kilometers west of the Nevada Test Site on a major north-trending ridge at Yucca Mountain, was dry drilled in Tertiary tuff to a depth of 575 meters. The area near this site is being considered by the U.S. Department of Energy for potential construction of a high-level, radioactive-waste repository. Test hole USW UZ-6 is one of seven test holes completed in the unsaturated zone as part of the U.S. Geological Survey's Yucca Mountain Project to characterize the potential repository site. Data pertaining to borehole drilling and construction, lithology of geologic units penetrated, and laboratory analyses for hydrologic characteristics of samples of drill-bit cuttings are included in this report.
\end{abstract}

Test hole USW UZ-6 penetrated an estimated 77 percent of the unsaturated zone present at the drilling site. No saturated perched water zones were encountered while drilling. Samples of drill-bit cuttings were collected at selected intervals for determining lithology, water content, and water potential of the geologic units penetrated.

The water content in the samples collected is related to the degree of welding of the rock units; densely welded tuff is relatively dry; nonwelded and bedded tuff is relatively moist. Average values of gravimetric water content for the driest zones of the densely welded sections of the Miocene Tiva Canyon Member and the Topopah Spring Member of the Paintbrush Tuff were 0.024 and 0.020 gram per gram, respectively; the average values of water potential were $-7,500$ and $-16,000$ kilopascals, respectively. Average values of gravimetric water content for the nonwelded tuff of the Tiva Canyon Member and the bedded tuff unit of the Paintbrush Tuff were 0.107 and 0.121 gram per gram, respectively; average values of water potential were -270 and -74 kilopascals, respectively.

\footnotetext{
${ }^{1}$ U.S. Geological Survey, Denver, Colorado.

${ }^{2}$ Foothill Engineering Consultants, Inc., Golden, Colorado.
} 


\section{INTRODUCTION}

As part of the U.S. Department of Energy's program pertaining to the storage of radioactive wastes, the U.S. Geological Survey is studying Yucca Mountain, Nevada (fig. 1), to evaluate the geologic and hydrologic suitability of this mountain for the potential storage of high-level radioactive wastes in an underground mined repository (Waddell, 1982; Roseboom, 1983; Montazer and Wilson, 1984; Squires and Young, 1984; Waddell and others, 1984). The principal method of investigation has been test-hole drilling. The test-hole drilling is a part of the Hydrologic Investigations Program of the U.S. Geological Survey's Yucca Mountain Project that is being conducted in cooperation with the U.S. Department of Energy, Nevada Field Office, as part of Interagency Agreement DE-AI08-78ET44802.

Test hole USW UZ-6 (hereafter referred to as test hole UZ-6) is the deepest $(575 \mathrm{~m})$ dry drilled borehole completed to date in a series of seven unsaturated-zone test holes drilled in the Yucca Mountain area. Test hole UZ-6 is located in Nye County, about $145 \mathrm{~km}$ northwest of Las Vegas just outside the west boundary of the Nevada Test Site (fig. 1). Test hole UZ-6 is located at the crest of a major north-trending ridge on Yucca Mountain at an altitude of $1,501 \mathrm{~m}$ (top of drill pad) above sea level. Surveying was done by Raytheon Services Nevada ${ }^{1}$ (formerly Holmes and Narver, Inc).

Additional data was obtained from test hole USW UZ-6s (hereafter referred to as test hole UZ-6s) that was drilled about $95 \mathrm{~m}$ to the west of test hole UZ-6. Test hole UZ-6s was drilled to provide an uncased upper zone for instrumentation of the unsaturated, densely welded Tiva Canyon Member of the Paintbrush Tuff. The upper $80.8 \mathrm{~m}$ of test hole UZ-6 was cased during drilling.

The main objectives of the deep unsaturated-zone drilling and testing program are: (1) To determine the flux of water moving through the unsaturated nonwelded and bedded tuff units and to determine if perched water zones exist; (2) to determine a vertical profile of water content, water potential, and other important hydrologic characteristics of the rock units penetrated; and (3) to monitor, by downhole instruments, the hydrologic changes that occur over an extended span of time and to provide data for the calculation of flux in nonwelded and bedded tuff.

The purpose of this report is to present the geohydrologic data obtained in the dry drilling of test hole UZ-6. In addition to lithologic descriptions, gravimetric water contents, and water potential data, the report includes the techniques used in the drilling, collecting, handling, and laboratory testing of the volcanic rocks penetrated in this test hole.

\footnotetext{
${ }^{1}$ The use of firm, trade, product, or industry names in this report is for identification or location purposes only and does not constitute endorsement of products by the U.S. Geological Survey nor impute responsibility for any present or potential effects on the natural resources.
} 


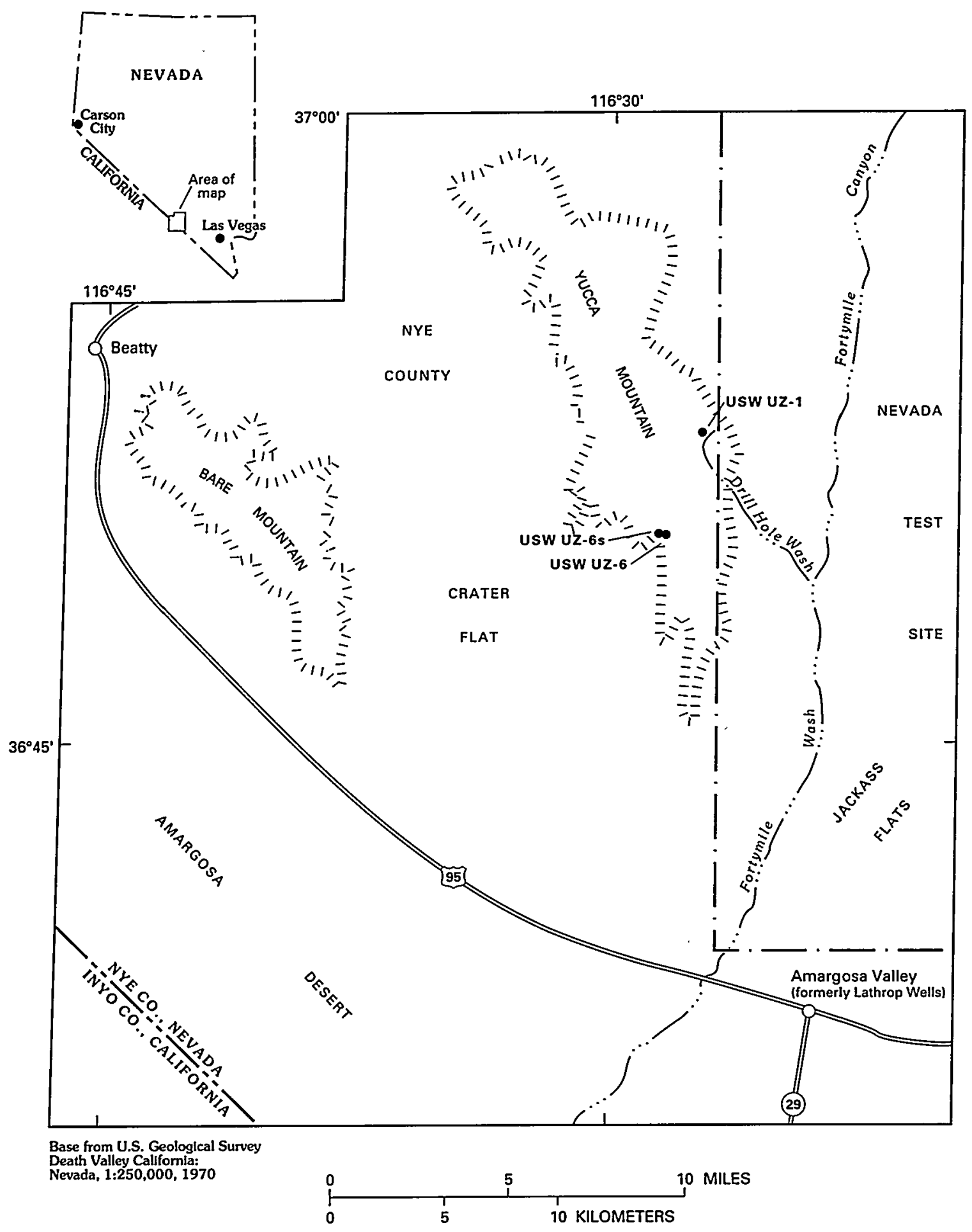

Figure 1.--Location of test holes USW UZ-1, USW UZ-6, and USW UZ-6s and nearby geographic features in southern Nevada (modified from Whitfield and others, 1990, fig. 1.). 


\section{Drilling Procedures}

The drilling of test hole UZ- 6 was the second attempt at the Yucca Mountain site to drill through the unsaturated zone to the water table using the vacuum reverse-air-circulation method of dry drilling. The first attempt was made in 1983 in test hole USW UZ-1, (fig. 1, Whitfield and others, 1990). Drilling of test hole UZ-6 began June 18, 1984, and ended on September 26, 1984. The unsaturated zone at this site is about $777 \mathrm{~m}$ thick. No saturated perched water zones were found during the drilling of this test hole. Drilling terminated at a depth of $575 \mathrm{~m}$ because of an overrun of drilling time caused by numerous borehole cavings and excessive breakage of the inner string of the dual-string drill pipe. Continual caving occurred to a depth of $305 \mathrm{~m}$ because of the numerous fractures in the densely welded tuff of the lower Tiva Canyon Member and in the upper one-half of the Topopah Spring Member of the Miocene Paintbrush Tuff.

Drilling of test hole UZ-6 was accomplished by using a dual-string, vacuum reverse-air-circulation method of dry drilling. A schematic diagram showing the equipment used for the vacuum reverse-air-circulation method of dry drilling is shown in figure 2. The inner string was $14 \mathrm{~cm}$ in diameter and the outer string was $22 \mathrm{~cm}$ in diameter. A vacuum unit or blower located on the land surface created suction in the inner string of the drill pipe to move the drill-bit cuttings from the bottom of the drill hole to the land surface. From the inner string, the drill-bit cuttings were routed by way of the kelly hose to a dry separator for sample collection. The dry separator contained two chambers separated by a hydraulic slide gate that prevented a vacuum loss in the upper chamber while drill-bit cuttings were being collected from the lower chamber. This system provided the capability for simultaneous drilling and sample collection. When closed, the slide gate allowed drill-bit cuttings to accumulate in the upper compartment of the dry separator while drill cuttings were being collected from the lower compartment of the dry separator. After collecting samples for lithologic and hydrologic analysis, the remaining drill-bit cuttings were vibrated out of the lower chamber of the dry separator and removed from this collecting point by a conveyor belt.

The vacuum reverse-air-circulation method of dry drilling described by Whitfield (1985), the Odex $165 \mathrm{~T}$ downhole air-hammer drilling system, and the smaller-diameter Odex $115 \mathrm{~T}$ downhole air-hammer drilling system described by Hammermeister and others, 1985, minimally disturb the matrix water content of the drill-bit cuttings and the rock penetrated. It was demonstrated in the drilling of test hole UZ-6s by the Odex method that representative cores for determining hydrologic properties can be obtained from depths of as much as $158 \mathrm{~m}$. Representative cores for hydrologic properties were not obtained from test hole UZ- 6 using the vacuum reverse-air-circulation method of dry drilling. Smaller-diameter core samples $(12.7 \mathrm{~cm})$ possibly could be obtained using this drilling method, but this has not yet been attempted. 


\section{EXPLANATION}

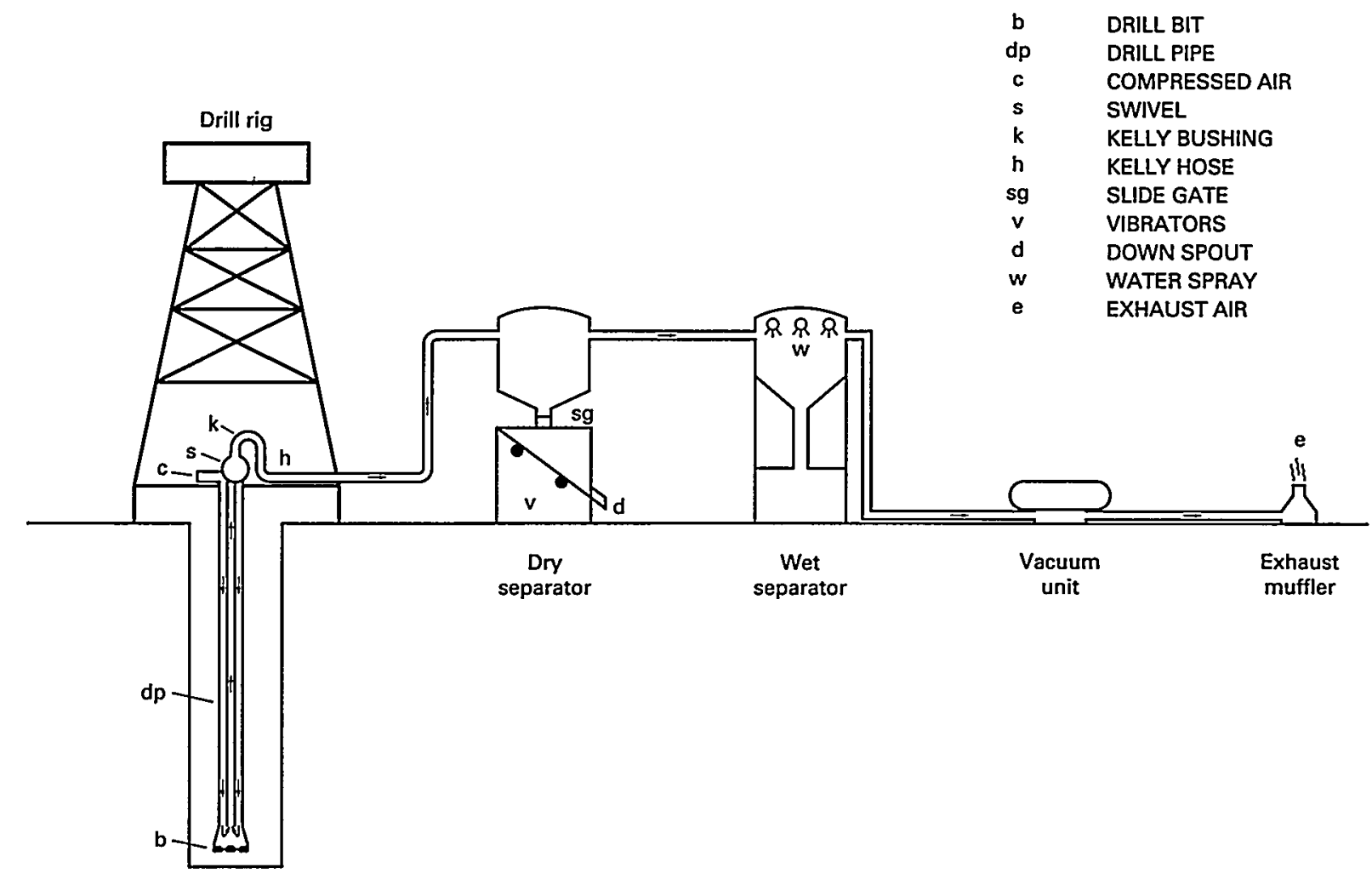

Figure 2.--Drill rig, separators, vacuum unit, and exhaust muffler for the vacuum reverse-air-circulation method of dry drilling (modified from Whitfield, 1985, fig. 2).

One of the major advantages of using the vacuum reverse-air-circulation method of dry drilling in unsaturated rocks is that moist zones or perched water zones can be determined immediately from the returned drill-bit cuttings. Another advantage is that the use of drilling fluids, such as water, drilling mud, or polymers, is not required so that the in-situ rock moisture and porosity is minimally disturbed. A disadvantage of the vacuum reverse-air-circulation method of dry drilling is the slower penetration rate when the in-situ rock water content is greater than about 5 percent by weight. In moist zones, plugging and encrustation of the drill bit, the inner string, and the kelly hose with a mud cake eventually restricts the flow of drill-bit cuttings to the land surface. When plugging occurs, drilling has to be stopped to prevent the drill bit from becoming buried in drill-bit cuttings, a situation that could eventually cause the bit to become stuck. This occurred during the drilling of test hole UZ-6 at a depth of $256 \mathrm{~m}$, and the drill pipe and bit had to be hydraulically jacked out of the borehole. Drilling can be resumed only after the bit, inner string, and kelly hose are cleaned and dried by blowing compressed air through them. If unstable borehole conditions exist, the vacuuming might increase cavings, and frequent re-drilling is required. 
Sulfur hexaflouride was injected into test hole UZ-6 as a tracer gas during drilling. Subsequent gas sampling in the borehole will determine the presence or absence of atmospheric contamination due to drilling in the rocks adjacent to the borehole. The gas was injected at a rate of approximately $40 \mathrm{~cm}^{3} / \mathrm{min}$ through the intake manifold of the air compressor. Compressed air was injected into the annulus between the inner pipe and the inside of the larger dual-wall pipe to help cool the drill bit and assist the vacuum system in removing drill-bit cuttings.

\section{Borehole Construction and Geologic Units Penetrated}

Test hole UZ-6 was drilled to a total depth of $575.2 \mathrm{~m}$. A $76.2-\mathrm{cm}-$ diameter borehole was drilled from the land surface to a depth of $12.2 \mathrm{~m}$ and cased with a $66.0-\mathrm{cm}$-diameter casing. The borehole diameter was decreased to $61.0 \mathrm{~cm}$ from a depth of $12.2 \mathrm{~m}$ to a depth of $103.9 \mathrm{~m}$ and cased to a depth of $98.8 \mathrm{~m}$ with 50.8 -cm-diameter casing. From a depth of $103.9 \mathrm{~m}$ to a depth of $575.2 \mathrm{~m}$, a $44.5-\mathrm{cm}$-diameter borehole was drilled and left uncased. A diagram showing final construction is provided in figure 3. A deviation survey indicated that the bottom of the borehole had a $3.61 \mathrm{~m}$ offset from the top of the borehole in a N. $76^{\circ} 44^{\prime} 39^{\prime \prime} \mathrm{E}$ direction (fig. 4).

The drilling rate and geologic units penetrated are shown in figure 5 . Only actual drilling time is indicated. The time needed to penetrate the rock is dependent on the lithology, primarily the degree of welding. Generally, the moderately and densely welded units required longer drilling times than nonwelded or partially welded units (fig. 6).

\section{GEOHYDROLOGIC DATA}

The geohydrologic data presented in this report consist of descriptions of the lithology of the geologic units penetrated in test hole UZ-6, gravimetric water-content measurements, and water-potential measurements. All the geohydrologic data are based on visual examination and laboratory analysis of drill-bit cuttings rather than of core samples.

Coring was not attempted in test hole UZ-6 because of the unsuccessful coring in test hole USW UZ-1 (Whitfield and others, 1990), caused by an inappropriate bit design for dry coring in a large-diameter borehole. Cores were overheated, thereby affecting the water content of the cores. Since the drilling of test hole UZ-6, changes have been made that decrease the borehole diameter enabling the use of more conventional coring bits for dry coring.

\section{Drill-Bit Cuttings}

\section{Collection and Processing}

Drill-bit cuttings were collected for the determination of lithologic and hydrologic characteristics. During the sampling and processing of drillbit cuttings, every effort was made to minimize the opportunity for water to evaporate from the cuttings. All procedures were designed to minimize water loss from the drill-bit cuttings from the time the samples left the borehole until laboratory water-content and water-potential measurements could be made. 


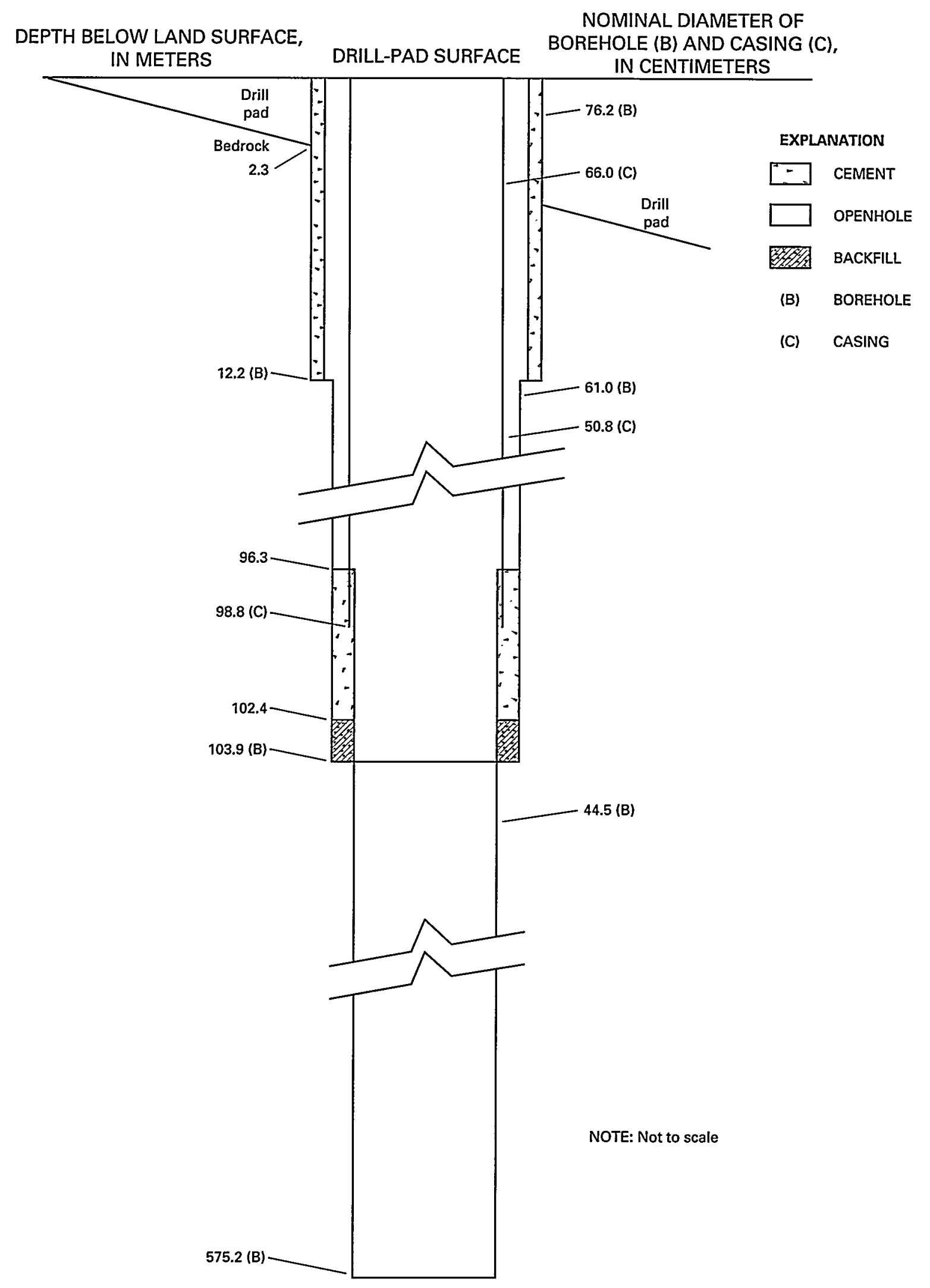

Figure 3.--Borehole construction. 


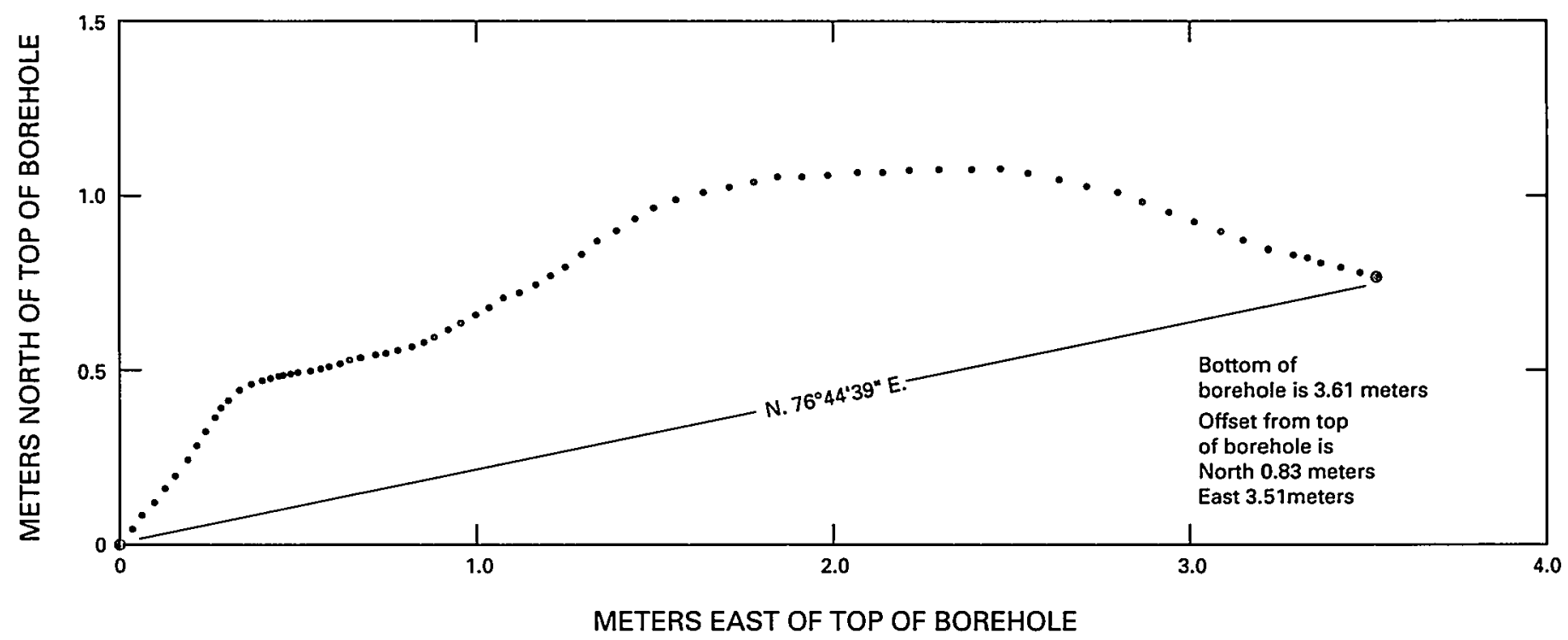

Figure 4.--Borehole deviation survey.

After drilling to a specified depth interval, the hydraulic slide gate on the dry separator was closed, separating the upper and lower compartments. This prevented vacuum loss in the borehole circulation system without disrupting drilling and allowed drill-bit cuttings to be removed from the lower compartment. The onsite geologist collected a lithologic sample from this interval out of the discharge outlet located at the base of the lower compartment of the dry separator. Drilling continued while the lithologic sample was being collected; concurrently, drill-bit cuttings for hydrologic sampling were accumulating in the upper compartment of the dry separator. The lower compartment was then emptied of drill-bit cuttings before opening the hydraulic slide gate and allowing the drill-bit cuttings of the upper compartment to drop into the lower compartment of the dry separator. At a specified interval, a grab sample was collected for the determination of hydrologic properties. The sample collecting was done quickly to maintain the integrity of the hydrologic properties, such as water content and water potential. Use of the hydraulic slide gate permitted continuous drilling and enabled two separate samples to be collected. The dry separator was emptied after each collection interval in preparation for the next interval to avoid mixing of samples. Vibrators welded to the base of the dry separator helped dislodge material from the walls on the inside of the dry separator, thus preventing contamination of the drill-bit cuttings between sample-collection intervals.

A 0.5-I carton of drill-bit cuttings was collected to prepare a lithologic log of geologic units penetrated by the borehole. These samples were archived later at the Sample Management Facility, Area 25, Mercury, Nev. Two 1-L glass jars of drill-bit cuttings were collected at the same time at about 


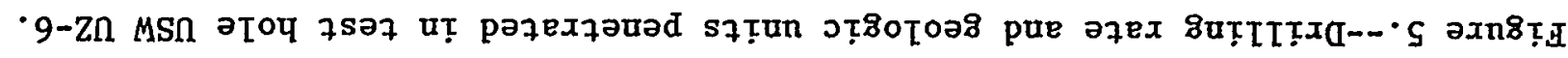

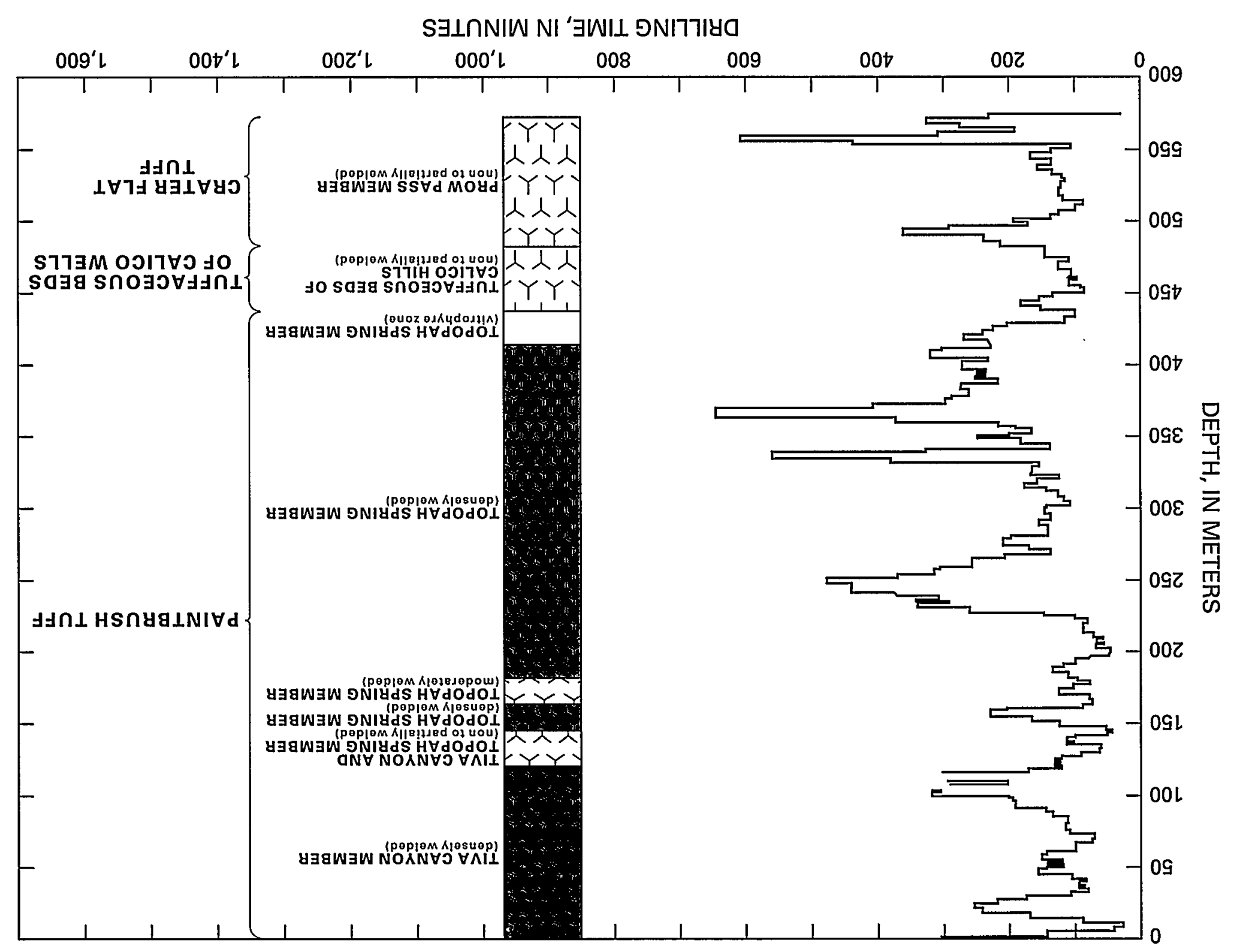


EXPLANATION
A: NONWELDED
B: PARTIALLY WELDED
C: MODERATELY WELDED
D: DENSELY WELDED

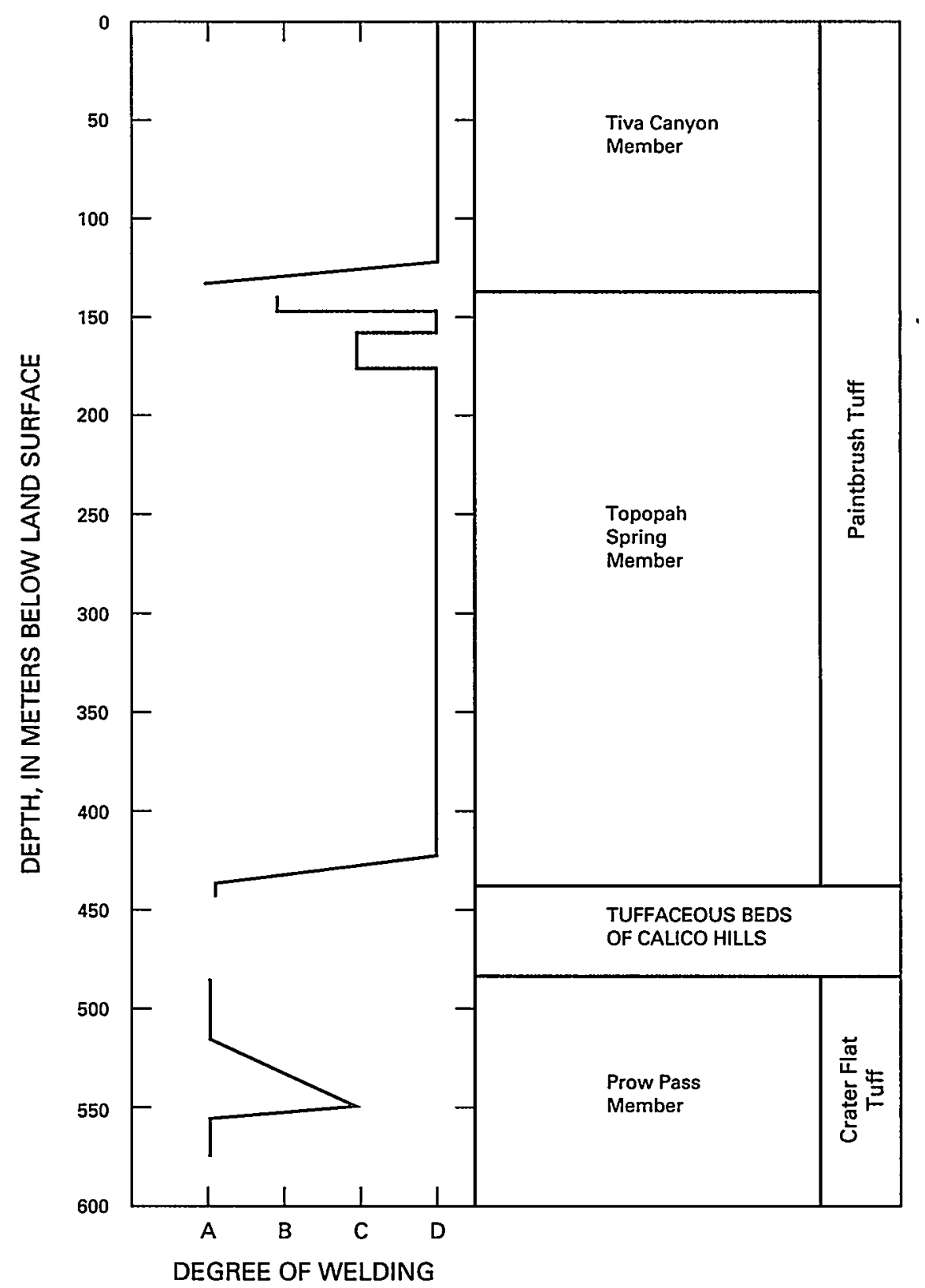

Figure 6.--Generalized distribution of welding in geologic units penetrated by test hole USW UZ- 6 . 
3.0-m intervals from a depth of $15.2 \mathrm{~m}$ to a depth of $575.1 \mathrm{~m}$ for laboratory measurements of water content and water potential. These jars were capped immediately with air-tight lids, taken to the onsite laboratory as soon as possible, and placed inside a humidified glove box.

The drill-bit cuttings for hydrologic-property tests in the laboratory were separated into coarse-, fine-, and composite-size fractions. Coarse-size samples consisted of drill-bit cuttings that would not pass through a screen with 1.6-mm openings; fine-size samples consisted of drill-bit cuttings that would pass through the screen. Samples taken directly from the $1-\mathrm{I}$ jars were designated as composite samples. These samples were analyzed to determine which size fraction compared the closest to the water-content and waterpotential measurements from core samples taken from other boreholes located in the area. Sample preparation was done inside a humidified glove box. Coarseand fine-size drill-bit cuttings were collected for water-potential measurements to a depth of $110 \mathrm{~m}$; at deeper depths, coarse-size drill-bit cuttings generally were collected. Fine- or composite-size drill-bit cuttings were collected if sufficient coarse-size drill-bit cuttings were not available. Samples for determination of gravimetric water content were placed in preweighed 420-mL moisture cans, covered, and immediately weighed. Samples for determination of water potential were placed in small jars ( $120 \mathrm{~mL}$ or less), capped, taped, labeled, sealed with wax, and stored in a cool environment $\left(20\right.$ to $\left.25^{\circ} \mathrm{C}\right)$ until measurements could be made.

\section{Lithology of Geologic Units Penetrated}

The geologic units penetrated by test hole UZ- 6 are tuffaceous units of Miocene age. Lithologic descriptions based on visual examination of drill-bit cuttings are given in table 1 . Ash-flow and ash-fall tuff are the predominant rock types in this section.

\section{Table 1.--Lithologic log of drill-bit cuttings from test hole USW UZ-6}

[Log compiled by Richard W. Spengler, Geologist, U.S. Geological Survey]

Stratigraphy and

lithologic description
Thickness of interval Depth of interval (meters) (meters)

Paintbrush Tuff of Miocene age

Tiva Canyon Member

Tuff, ash flow, light-brownishgray, brownish-gray, grayishbrown, densely welded, devitrified; pumice, very light gray, light-brownishgray, brownish-gray, and light-brown, devitrified; 1 to 3 percent phenocrysts (sanidine and biotite); base of unit inferred from density and induction logs and verified on televisioncamera log. 
Table 1.--Lithologic log of drill-bit cuttings from test hole USW UZ-6--Continued

\begin{tabular}{|c|c|c|}
\hline $\begin{array}{l}\text { Stratigraphy and } \\
\text { lithologic description }\end{array}$ & $\begin{array}{l}\text { Thickness of interval } \\
\text { (meters) }\end{array}$ & $\begin{array}{c}\text { Depth of interval } \\
\text { (meters) }\end{array}$ \\
\hline $\begin{array}{l}\text { Tuff, ash flow, dark-gray to } \\
\text { brownish-black, densely welded, } \\
\text { glassy (vitrophyre); pumice, } \\
\text { moderately-brown to black, } \\
\text { vitric; } 1 \text { to } 3 \text { percent pheno- } \\
\text { crysts (commonly sanidine); } \\
\text { base of unit inferred from } \\
\text { density and induction logs } \\
\text { and verified on television- } \\
\text { camera logs. }\end{array}$ & 7.3 & 123.4 \\
\hline $\begin{array}{l}\text { Tuff, ash flow, light-brown to } \\
\text { moderate-brown, moderately to } \\
\text { partially welded, vitric; } \\
\text { pumice, light-brown to brownish- } \\
\text { black, vitric; } 1 \text { to } 3 \text { percent } \\
\text { phenocrysts (predominantly sani- } \\
\text { dine and biotite); abundant dark- } \\
\text { yellowish-orange to light-brown } \\
\text { glass shards. }\end{array}$ & 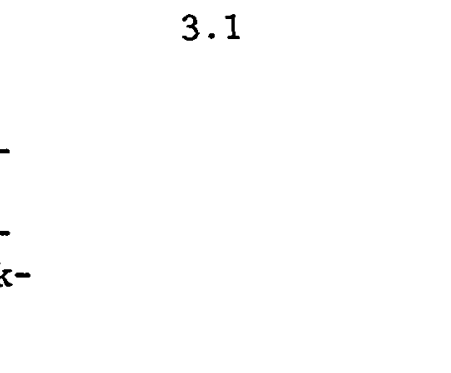 & 126.5 \\
\hline $\begin{array}{l}\text { Tuff, ash flow, light-brown to } \\
\text { moderate-brown, nonwelded, } \\
\text { vitric; pumice, light-brown, } \\
\text { vitric; } 1 \text { to } 2 \text { percent pheno- } \\
\text { crysts (sanidine and biotite); } \\
\text { abundant dark-yellowish-orange } \\
\text { to light-brown glass shards; } \\
\text { base of unit inferred from } \\
\text { density log and verified on } \\
\text { television-camera log. } \\
\text { Bedded Tuff }\end{array}$ & 5.6 & 132.1 \\
\hline $\begin{array}{l}\text { Tuff, ash fall and reworked, } \\
\text { light-gray, light-olive- } \\
\text { gray, light-brown, moderate- } \\
\text { brown, and grayish-red, } \\
\text { poorly consolidated(?), } \\
\text { vitric; composed predominantly } \\
\text { of light-gray and light-olive } \\
\text { gray pumice clasts and pale-red } \\
\text { and grayish-red volcanic lithic } \\
\text { fragments; lower part appears } \\
\text { moderate-brown and grayish-red } \\
\text { and highly argillic(?); base of } \\
\text { unit identified on television- } \\
\text { camera log. }\end{array}$ & 5.6 & 137.7 \\
\hline
\end{tabular}


Table 1.--Lithologic log of drill-bit cuttings from test hole USW UZ-6--Continued

\begin{tabular}{|c|c|c|}
\hline $\begin{array}{l}\text { Stratigraphy and } \\
\text { lithologic description }\end{array}$ & $\begin{array}{c}\text { Thickness of interval } \\
\text { (meters) }\end{array}$ & $\begin{array}{c}\text { Depth of interval } \\
\text { (meters) }\end{array}$ \\
\hline $\begin{array}{l}\text { Paintbrush Tuff of Miocene age } \\
\text { Topopah Spring Member } \\
\text { Tuff, ash flow and ash fall(?), } \\
\text { light-brownish-gray to brown- } \\
\text { ish-gray, partially welded(?), } \\
\text { vitric; composed predominantly } \\
\text { of pumice clasts, light- } \\
\text { brownish-gray to brownish-gray; } \\
\text { base of unit identified on den- } \\
\text { sity and television-camera logs. } \\
\text { Tuff, ash flow, grayish-red, } \\
\text { densely welded, devitrified } \\
\text { (caprock); pumice, grayish- } \\
\text { red and light-brown, devitri- } \\
\text { fied; 10(?) percent phenocrysts } \\
\text { (sanidine and bronze biotite); } \\
\text { a few fragments of vitrophyre } \\
\text { in samples indicate the upper } \\
\text { few meters might be the upper } \\
\text { vitrophyre; bit-cutting samples } \\
\text { from } 146.3 \text { to 149.4 meters are } \\
\text { highly contaminated. } \\
\text { Tuff, ash flow, light-brown to } \\
\text { pale-brown, moderately welded, } \\
\text { devitrified (vapor phase } \\
\text { crystallization); pumice, light- } \\
\text { brown and very light-gray, } \\
\text { predominantly vapor phase } \\
\text { crystallization; } 5(?) \text { percent } \\
\text { phenocrysts (sanidine and } \\
\text { biotite); base of unit dis- } \\
\text { played on density log and } \\
\text { verified on television-camera } \\
\text { log. } \\
\text { Tuff, ash flow, pale-red and } \\
\text { light-gray, densely welded, } \\
\text { devitrified; pumice, light } \\
\text { gray and pale-red, devitrified; } \\
\text { 1 percent phenocrysts } \\
\text { (sanidine); upper lithophysal } \\
\text { zone based on television-camera } \\
\text { log. }\end{array}$ & 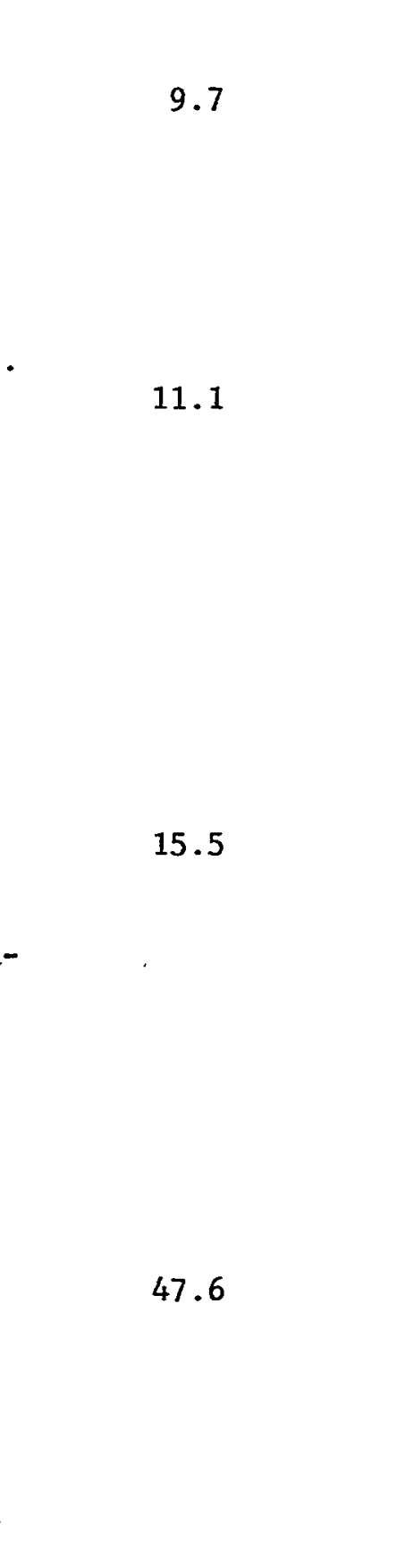 & 158.5 \\
\hline
\end{tabular}


Table 1.--Lithologic log of drill-bit cuttings from test hole USW UZ-6--Continued

Stratigraphy and lithologic description

Tuff, ash flow, light-brown, dark-yellowish-brown, and moderate-brown, densely welded, devitrified; pumice, lightbrown, and moderate-brown, devitrified; 1 percent

phenocrysts (sanidine); identification of non-lithophysal zone based on television-camera log.

Tuff, ash flow, light-brown, moderate-brown, and pale-red, densely welded, devitrified; pumice, light-brown, devitrified; 1 percent phenocrysts (sanidine); interval contains lower lithophysal zone from 277.9 to 361.5 meters and lower nonlithophysal zone from 361.5 meters to base of unit; zones identified from televisioncamera log.

Tuff, ash flow, black, densely welded, glassy, (vitrophyre); 1 percent phenocrysts (sanidine); lower contact is gradational.

Tuff, ash flow, dark-gray, moderately welded, glassy; pumice, grayish-black, vitric; 1 percent phenocrysts (sanidine); base of unit identified from televisioncamera log.

Tuff, ash flow, light-brown to moderate-brown, partially to nonwelded, vitric; pumice, grayish-black and lightbrown, vitric; 2 percent phenocrysts (sanidine); abundant black glass shards; grayish-red volcanic lithic fragments present; base of unit was not identified in bit-cutting samples, but from television-camera $\log$ as a change in lithology.
Thickness of interval Depth of interval (meters)

(meters)

278.0
409.5

11.1

420.6

2.2

422.8

15.2

438.0 
Table 1.--Lithologic log of drill-bit cuttings from test hole USW UZ-6--Continued

\begin{tabular}{|c|c|c|}
\hline $\begin{array}{l}\text { Stratigraphy and } \\
\text { lithologic description }\end{array}$ & $\begin{array}{l}\text { Thickness of interval } \\
\text { (meters) }\end{array}$ & $\begin{array}{c}\text { Depth of interval } \\
\text { (meters) }\end{array}$ \\
\hline $\begin{array}{l}\text { Tuffaceous beds of Calico Hills } \\
\text { (informal) }\end{array}$ & & \\
\hline $\begin{array}{l}\text { Tuff, ash fall and ash flow } \\
\text { light-brown and very pale } \\
\text { orange, poorly consolidated, } \\
\text { vitric; predominantly composed } \\
\text { of very pale-orange and light- } \\
\text { brown pumice clasts, vitric; } \\
\text { rare phenocrysts (sanidine } \\
\text { and biotite); based on tele- } \\
\text { vision-camera log, slight } \\
\text { change in lithology recognized } \\
\text { at } 455.7 \text { meters and possible } \\
\text { bedding plane seen at } \\
466.2 \text { meters; base of unit } \\
\text { also identified from tele- } \\
\text { vision-camera log. }\end{array}$ & 33.6 & 471.6 \\
\hline $\begin{array}{l}\text { Tuff, bedded, reworked, } \\
\text { tuffaceous sandstone, } \\
\text { moderate-reddish brown, } \\
\text { light-brown, and grayish- } \\
\text { orange, poorly consolidated, } \\
\text { well sorted, vitric; bit- } \\
\text { cutting samples are rich in } \\
\text { well-rounded phenocrysts } \\
\text { (predominantly sanidine) and } \\
\text { grayish-orange pumice clasts, } \\
\text { vitric; samples highly contam- } \\
\text { inated from } 478.5 \text { to } 481.6 \\
\text { meters; possible bedding planes } \\
\text { identified from the television- } \\
\text { camera log at } 473.1,474.5, \\
475.7,477.2, \text { and } 483.0 \text { meters. } \\
\text { Crater Flat Tuff } \\
\text { Prow Pass Member }\end{array}$ & 11.4 & 483.0 \\
\hline $\begin{array}{l}\text { Tuff, ash flow, grayish-orange- } \\
\text { pink, nonwelded, vitric; pumice, } \\
\text { very light-gray, vitric (some } \\
\text { vapor phase crystallization); } \\
8 \text { to } 10 \text { percent phenocrysts } \\
\text { (quartz, sanidine, biotite, } \\
\text { pyroxene pseudomorphs); } \\
\text { rock in interval from } 490.7 \\
\text { to } 493.8 \text { meters indicates a } \\
\text { zone predominantly composed } \\
\text { of pumice having vapor phase } \\
\text { crystallization; samples from }\end{array}$ & , & 514.6 \\
\hline
\end{tabular}


Table 1.--Lithologic log of drill-bit cuttings from test hole USW UZ-6--Continued

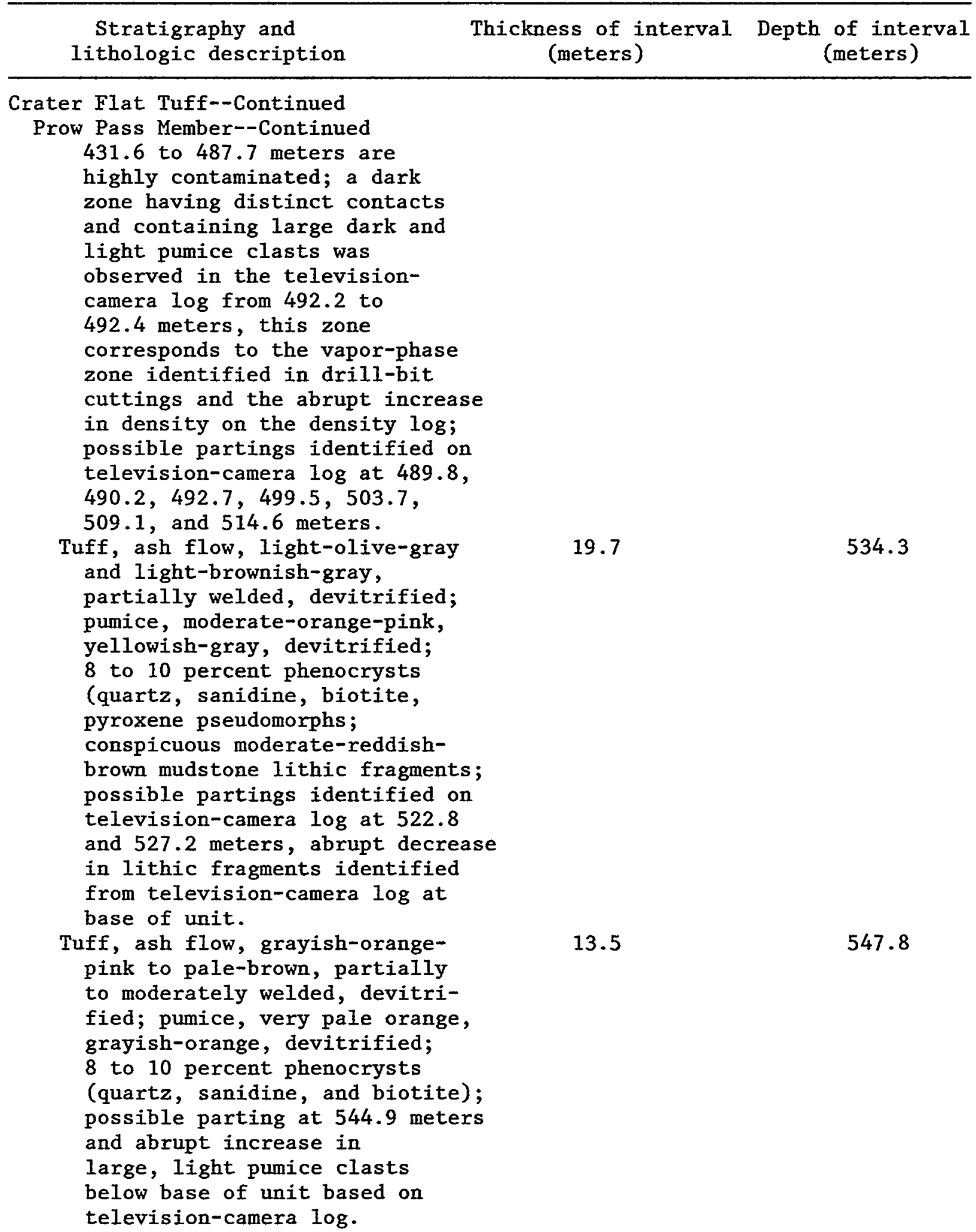


Table 1.--Lithologic log of drill-bit cuttings from test hole USW UZ-6--Continued

\begin{tabular}{|c|c|c|}
\hline $\begin{array}{l}\text { Stratigraphy and } \\
\text { lithologic description }\end{array}$ & $\begin{array}{c}\text { Chickness of interval } \\
\text { (meters) }\end{array}$ & $\begin{array}{c}\text { Depth of interval } \\
\text { (meters) }\end{array}$ \\
\hline $\begin{array}{l}\text { Tuff, ash flow, very light-gray, } \\
\text { non to partially welded, } \\
\text { devitrified; pumice, very light } \\
\text { gray and very pale orange, } \\
\text { devitrified; } 5 \text { to } 7 \text { percent } \\
\text { phenocrysts (quartz, sanidine, } \\
\text { biotite); abundant minute } \\
\text { biotite flakes throughout } \\
\text { matrix; moderate-reddish- } \\
\text { brown mudstone lithic frag- } \\
\text { ments present; possible } \\
\text { partings identified at } 553.8 \\
\text { and } 554.7 \text { meters and abrupt } \\
\text { change to darker lithology } \\
\text { seen at } 554.7 \text { meters based on } \\
\text { television-camera log. }\end{array}$ & 6.9 & 554.7 \\
\hline $\begin{array}{l}\text { Tuff, ash flow, grayish-orange- } \\
\text { pink, nonwelded(?), vitric(?), } \\
\text { and slightly altered(?); } \\
\text { pumice, very pale orange and } \\
\text { grayish-orange-pink, vitric } \\
\text { [slightly argillic(?) and } \\
\text { zeolitic(?)]; 10 percent pheno- } \\
\text { crysts (quartz, sanidine, } \\
\text { biotite, and pyroxene); } \\
\text { abundant moderate-reddish- } \\
\text { brown mudstone l-ithic fragments; } \\
\text { possible partings(?) identi- } \\
\text { fied at 558.3 and } 564.4 \text { meters } \\
\text { and lithic-fragment swarm at } \\
563.6 \text { meters based on television- } \\
\text { camera log; fill encountered in } \\
\text { hole at a depth of } 565.2 \text { meters. }\end{array}$ & - & 575.2 \\
\hline
\end{tabular}

*The top 2.3 meters of material in this borehole represent fill material used to construct the drill pad.

\section{Gravimetric Water-Content Measurements}

Gravimetric water-content measurements were made onsite in a U.S. Geological Survey field-laboratory trailer using standard gravimetric ovendrying methods (Gardner, 1965). Moisture cans of known weight were filled with drill-bit cuttings, capped, and immediately weighed. These moisture cans were weighed again after baking in an oven for a minimum of 18 hours at $10{ }^{\circ} \mathrm{C}$. The gravimetric water content of a given sample of drill-bit. cuttings, in grams per gram, equals the water lost through drying divided by 
the weight of the dried sample. Results of laboratory analysis for gravimetric water content for coarse drill-bit cuttings are tablulated in table 2 . This table also includes the results of laboratory analysis for waterpotential measurements that are discussed in the "Water-Potential Measurements" section of this report. The depths from which drill-bit cuttings were collected for hydrologic laboratory analysis also are listed in table 2 and represent a spot sample from the approximate depth given and not an average for a large interval.

Table 2.--Results of laboratory analyses for gravimetric water-content and water-potential measurements of drill-bit cuttings from test hole USW UZ-6

[--, indicates no data; >, greater than]

\begin{tabular}{|c|c|c|c|c|c|c|}
\hline \multirow{2}{*}{$\begin{array}{l}\text { Depth } \\
\text { (meters) }\end{array}$} & \multicolumn{3}{|c|}{$\begin{array}{l}\text { Gravimetric water content } \\
\text { (gram per gram) }\end{array}$} & \multicolumn{3}{|c|}{$\begin{array}{c}\text { Water potential } \\
\text { (negative kilopascals) }\end{array}$} \\
\hline & Coarse & Fine & Composite & Coarse & Fine & Composite \\
\hline 13.7 & 0.021 & 0.020 & 0.020 & -- & -- & -- \\
\hline 13.7 & 0.022 & 0.020 & 0.020 & -- & -- & -- \\
\hline 15.2 & 0.032 & 0.030 & 0.030 & -- & -- & -- \\
\hline 15.2 & 0.030 & 0.028 & 0.028 & -- & -- & -- \\
\hline 18.3 & 0.026 & 0.024 & 0.024 & -- & -- & -- \\
\hline 18.3 & 0.027 & 0.025 & 0.025 & -- & -- & -- \\
\hline 21.3 & 0.031 & 0.030 & 0.033 & - & - & $\ldots$ \\
\hline 21.3 & 0.035 & 0.032 & -- & -- & - & -- \\
\hline 24.4 & 0.025 & 0.014 & 0.018 & -- & - & -- \\
\hline 24.4 & 0.025 & 0.013 & 0.020 & -- & -- & -- \\
\hline 27.4 & 0.027 & 0.022 & 0.022 & -- & -- & -- \\
\hline 27.4 & 0.031 & 0.020 & 0.024 & -- & -- & -- \\
\hline 30.5 & 0.032 & 0.027 & 0.030 & -- & -- & -- \\
\hline 30.5 & 0.031 & 0.027 & 0.029 & -- & -- & -- \\
\hline 33.5 & 0.033 & 0.022 & 0.027 & -- & -- & -- \\
\hline 33.5 & 0.030 & 0.020 & 0.025 & -- & -- & -- \\
\hline 36.6 & 0.052 & 0.047 & 0.052 & -- & -- & -- \\
\hline 36.6 & 0.049 & 0.045 & 0.048 & -- & -- & -- \\
\hline 39.6 & 0.040 & 0.035 & 0.039 & -- & -- & -- \\
\hline 39.6 & 0.043 & 0.040 & 0.042 & -- & -- & -- \\
\hline 42.7 & 0.032 & 0.024 & 0.029 & -- & -- & -- \\
\hline 42.7 & 0.033 & 0.025 & 0.029 & -- & -- & -- \\
\hline 45.7 & 0.034 & 0.028 & 0.031 & -- & -- & -- \\
\hline 45.7 & 0.032 & 0.026 & 0.029 & -- & -- & -- \\
\hline 48.8 & 0.032 & 0.021 & 0.025 & $-3,300$ & $-1,400$ & -- \\
\hline
\end{tabular}


Table 2.--Results of laboratory analyses for gravimetric water-content and water-potential measurements of drill-bit cuttings from test hole USW UZ-6--Continued

\begin{tabular}{|c|c|c|c|c|c|c|}
\hline \multirow{2}{*}{$\begin{array}{l}\text { Depth } \\
\text { (meters) }\end{array}$} & \multicolumn{3}{|c|}{$\begin{array}{c}\text { Gravimetric water content } \\
\text { (gram per gram) }\end{array}$} & \multicolumn{3}{|c|}{$\begin{array}{l}\text { Water potential } \\
\text { (negative kilopascals) }\end{array}$} \\
\hline & Coarse & Fine & Composite & Coarse & Fine & Composite \\
\hline $\begin{array}{l}51.8 \\
54.9 \\
57.9 \\
61.0 \\
64.0\end{array}$ & $\begin{array}{l}0.026 \\
0.023 \\
0.028 \\
0.036 \\
0.027\end{array}$ & $\begin{array}{l}0.015 \\
0.012 \\
0.017 \\
0.032 \\
0.014\end{array}$ & $\begin{array}{l}0.021 \\
0.017 \\
0.025 \\
0.034 \\
0.021\end{array}$ & $\begin{array}{r}-2,500 \\
-4,700 \\
-1,800 \\
-930 \\
-3,100\end{array}$ & $\begin{array}{r}-3,000 \\
-6,300 \\
-2,800 \\
-610 \\
-4,200\end{array}$ & $\begin{array}{l}-- \\
-- \\
-- \\
--\end{array}$ \\
\hline $\begin{array}{l}67.1 \\
70.1 \\
73.1 \\
76.2 \\
79.2\end{array}$ & $\begin{array}{l}0.025 \\
0.028 \\
0.027 \\
0.026 \\
0.026\end{array}$ & $\begin{array}{l}0.016 \\
0.016 \\
0.017 \\
0.016 \\
0.017\end{array}$ & $\begin{array}{l}0.021 \\
0.022 \\
0.023 \\
0.021 \\
0.022\end{array}$ & $\begin{array}{l}-3,000 \\
-2,400 \\
-2,000 \\
-1,200 \\
-2,500\end{array}$ & $\begin{array}{l}-4,200 \\
-2,700 \\
-1,900 \\
-2,000 \\
-3,200\end{array}$ & $\begin{array}{l}-- \\
-- \\
-- \\
-- \\
--\end{array}$ \\
\hline $\begin{array}{l}82.3 \\
85.3 \\
88.4 \\
91.4 \\
91.4\end{array}$ & $\begin{array}{c}0.021 \\
0.020 \\
0.016 \\
0.021 \\
--\end{array}$ & $\begin{array}{c}0.013 \\
0.014 \\
0.009 \\
0.016 \\
--\end{array}$ & $\begin{array}{l}0.017 \\
0.017 \\
0.012 \\
0.019 \\
--\end{array}$ & $\begin{array}{c}-4,300 \\
-3,500 \\
-6,700 \\
-4,100 \\
--\end{array}$ & $\begin{array}{l}-4,900 \\
-5,600 \\
-6,300 \\
-3,800 \\
-6,100\end{array}$ & $\begin{array}{l}-- \\
-- \\
-- \\
-- \\
--\end{array}$ \\
\hline $\begin{array}{r}94.5 \\
97.5 \\
100.6 \\
103.6 \\
106.7\end{array}$ & $\begin{array}{l}0.022 \\
0.026 \\
0.015 \\
0.011 \\
0.006\end{array}$ & $\begin{array}{l}0.017 \\
0.028 \\
0.012 \\
0.007 \\
0.004\end{array}$ & $\begin{array}{l}0.018 \\
0.028 \\
0.013 \\
0.009 \\
0.004\end{array}$ & $\begin{array}{r}-4,000 \\
-1,000 \\
-8,400 \\
-14,000 \\
-28,000\end{array}$ & $\begin{array}{r}-3,600 \\
-1,100 \\
-5,500 \\
-13,000 \\
-47,000\end{array}$ & $\begin{array}{l}-- \\
-- \\
-- \\
-- \\
--\end{array}$ \\
\hline $\begin{array}{l}109.7 \\
112.8 \\
115.8 \\
118.9 \\
121.9\end{array}$ & $\begin{array}{c}0.006 \\
-- \\
0.014 \\
0.009 \\
0.012\end{array}$ & $\begin{array}{l}0.005 \\
-- \\
0.013 \\
0.006 \\
0.010\end{array}$ & $\begin{array}{c}0.005 \\
-- \\
0.013 \\
0.007 \\
0.011\end{array}$ & $\begin{array}{c}-13,000 \\
- \\
-10,000 \\
-23,000 \\
-24,000\end{array}$ & $\begin{array}{c}-43,000 \\
-- \\
-- \\
-- \\
--\end{array}$ & $\begin{array}{l}-- \\
-- \\
-- \\
--\end{array}$ \\
\hline $\begin{array}{l}121.9 \\
125.0 \\
126.2 \\
127.1 \\
128.0\end{array}$ & $\begin{array}{c}-- \\
0.042 \\
0.103 \\
0.134 \\
0.117\end{array}$ & $\begin{array}{l}--- \\
0.029 \\
0.075 \\
0.118 \\
0.105\end{array}$ & $\begin{array}{c}-- \\
0.041 \\
0.089 \\
0.126 \\
0.109\end{array}$ & $\begin{array}{r}-10,000 \\
-13,000 \\
-3,300 \\
-410 \\
-390\end{array}$ & $\begin{array}{l}-- \\
-- \\
-- \\
-- \\
--\end{array}$ & $\begin{array}{l}-- \\
-- \\
-- \\
-- \\
--\end{array}$ \\
\hline $\begin{array}{l}129.5 \\
130.4 \\
131.1 \\
132.6 \\
134.1\end{array}$ & $\begin{array}{l}0.118 \\
0.121 \\
0.093 \\
0.098 \\
0.123\end{array}$ & $\begin{array}{l}0.094 \\
0.098 \\
0.089 \\
0.085 \\
0.114\end{array}$ & $\begin{array}{l}0.099 \\
0.095 \\
0.089 \\
0.102 \\
0.114\end{array}$ & $\begin{array}{l}-240 \\
-- \\
-- \\
-- \\
--\end{array}$ & $\begin{array}{l}-- \\
-- \\
-- \\
-- \\
--\end{array}$ & $\begin{array}{l}-- \\
-- \\
>-50 \\
-160 \\
-52\end{array}$ \\
\hline
\end{tabular}


Table 2.--Results of laboratory analyses for gravimetric water-content and water-potential measurements of drill-bit cuttings from test hole USW UZ-6--Continued

\begin{tabular}{|c|c|c|c|c|c|c|}
\hline \multirow{2}{*}{$\begin{array}{l}\text { Depth } \\
\text { (meters) }\end{array}$} & \multicolumn{3}{|c|}{$\begin{array}{l}\text { Gravimetric water content } \\
\text { (gram per gram) }\end{array}$} & \multicolumn{3}{|c|}{$\begin{array}{l}\text { Water potential } \\
\text { (negative kilopascals) }\end{array}$} \\
\hline & Coarse & Fine & Composite & Coarse & Fine & Composite \\
\hline 135.6 & 0.146 & 0.130 & 0.129 & -- & -- & - \\
\hline 137.2 & 0.157 & 0.126 & 0.127 & -- & -- & $>-50$ \\
\hline 138.7 & 0.118 & 0.183 & 0.138 & -- & -- & -- \\
\hline 140.2 & 0.123 & 0.133 & 0.123 & -340 & -- & -- \\
\hline 141.7 & 0.101 & 0.125 & 0.114 & -- & -- & -- \\
\hline 143.2 & 0.081 & 0.079 & 0.071 & -220 & -- & -- \\
\hline 144.8 & 0.055 & 0.064 & 0.060 & -- & -- & -- \\
\hline 146.3 & 0.050 & 0.038 & 0.045 & -- & -- & -650 \\
\hline 147.8 & 0.077 & 0.071 & 0.070 & -- & -- & -- \\
\hline 149.3 & 0.047 & 0.060 & 0.045 & -460 & -- & -- \\
\hline 150.9 & 0.015 & 0.015 & 0.014 & -- & -- & -- \\
\hline 152.4 & 0.023 & 0.021 & 0.021 & $-3,400$ & -- & -- \\
\hline 155.4 & 0.025 & 0.025 & 0.024 & $-3,100$ & -- & $\ldots$ \\
\hline 158.5 & 0.026 & 0.023 & 0.024 & $-3,900$ & -- & -- \\
\hline 161.5 & 0.039 & 0.036 & 0.037 & -840 & -- & -- \\
\hline 164.6 & 0.029 & 0.026 & 0.024 & $-1,600$ & -- & -- \\
\hline 167.6 & 0.026 & 0.025 & 0.026 & $-1,900$ & -- & -- \\
\hline 170.7 & 0.024 & 0.025 & 0.025 & $-1,800$ & -- & -- \\
\hline 173.7 & 0.026 & 0.024 & 0.025 & $-1,800$ & -- & -- \\
\hline 176.8 & 0.032 & 0.030 & 0.030 & -740 & -- & -- \\
\hline 179.8 & 0.033 & 0.031 & 0.035 & -920 & -- & -- \\
\hline 182.9 & 0.034 & 0.032 & 0.032 & -810 & -- & -- \\
\hline 185.9 & 0.037 & 0.033 & 0.034 & -930 & -- & -- \\
\hline 189.0 & 0.037 & 0.034 & 0.033 & $-1,000$ & - & $\ldots$ \\
\hline 192.0 & 0.037 & 0.033 & 0.034 & -980 & -- & -- \\
\hline 195.1 & 0.037 & 0.035 & 0.037 & $-1,000$ & -- & -- \\
\hline 198.1 & 0.050 & 0.056 & 0.054 & -410 & -- & -- \\
\hline 201.2 & 0.049 & 0.053 & 0.051 & -720 & -- & -- \\
\hline 204.2 & 0.046 & 0.049 & 0.048 & -490 & -- & -. \\
\hline 207.3 & 0.043 & 0.045 & 0.044 & -840 & -- & - \\
\hline 210.3 & 0.043 & 0.045 & 0.043 & -780 & -- & -- \\
\hline 213.3 & 0.032 & 0.031 & 0.031 & $-1,800$ & - & - \\
\hline 216.4 & 0.036 & 0.035 & 0.035 & $-1,400$ & -- & -- \\
\hline 219.4 & 0.034 & 0.035 & 0.035 & -990 & -- & -- \\
\hline 222.5 & 0.028 & 0.026 & 0.027 & $-2,600$ & -- & -- \\
\hline
\end{tabular}


Table 2.--Results of laboratory analyses for gravimetric water-content and water-potential measurements of drill-bit cuttings from test hole USW UZ-6--Continued

\begin{tabular}{|c|c|c|c|c|c|c|}
\hline \multirow{2}{*}{$\begin{array}{l}\text { Depth } \\
\text { (meters) }\end{array}$} & \multicolumn{3}{|c|}{$\begin{array}{c}\text { Gravimetric water content } \\
\text { (gram per gram) }\end{array}$} & \multicolumn{3}{|c|}{$\begin{array}{l}\text { Water potential } \\
\text { (negative kilopascals) }\end{array}$} \\
\hline & Coarse & Fine & Composite & Coarse & Fine & Composite \\
\hline $\begin{array}{l}225.5 \\
228.6 \\
231.6 \\
234.7 \\
237.7\end{array}$ & $\begin{array}{l}0.020 \\
0.025 \\
0.008 \\
0.016 \\
0.009\end{array}$ & $\begin{array}{l}0.016 \\
0.020 \\
0.008 \\
0.014 \\
0.007\end{array}$ & $\begin{array}{l}0.016 \\
0.023 \\
0.008 \\
0.015 \\
0.006\end{array}$ & $\begin{array}{l}-- \\
-- \\
-- \\
--\end{array}$ & $\begin{array}{r}-7,300 \\
-3,500 \\
-28,000 \\
-19,000 \\
-16,000\end{array}$ & $\begin{array}{l}-- \\
-- \\
-- \\
--\end{array}$ \\
\hline $\begin{array}{l}240.8 \\
243.8 \\
246.9 \\
249.6 \\
253.0\end{array}$ & $\begin{array}{l}0.023 \\
0.009 \\
0.007 \\
0.007 \\
0.009\end{array}$ & $\begin{array}{l}0.013 \\
0.008 \\
0.006 \\
0.006 \\
0.009\end{array}$ & $\begin{array}{l}0.014 \\
0.007 \\
0.006 \\
0.006 \\
0.009\end{array}$ & $\begin{array}{l}-39,000 \\
-44,000 \\
-36,000 \\
-38,000\end{array}$ & $\begin{array}{l}-32,000 \\
-42,000 \\
-43,000 \\
-36,000 \\
-32,000\end{array}$ & $\begin{array}{l}-- \\
-- \\
-- \\
-- \\
--\end{array}$ \\
\hline $\begin{array}{l}256.3 \\
259.1 \\
262.1 \\
264.9 \\
268.2\end{array}$ & $\begin{array}{l}0.020 \\
0.030 \\
0.029 \\
0.037 \\
0.020\end{array}$ & $\begin{array}{l}0.017 \\
0.027 \\
0.026 \\
0.032 \\
0.016\end{array}$ & $\begin{array}{l}0.016 \\
0.028 \\
0.031 \\
0.033 \\
0.020\end{array}$ & $\begin{array}{l}-8,800 \\
-5,000 \\
-4,500 \\
-3,200 \\
-5,600\end{array}$ & $\begin{array}{l}-- \\
-- \\
-- \\
-- \\
--\end{array}$ & $\begin{array}{l}-- \\
-- \\
-- \\
-- \\
--\end{array}$ \\
\hline $\begin{array}{l}271.3 \\
274.3 \\
277.4 \\
280.4 \\
283.5\end{array}$ & $\begin{array}{l}0.021 \\
0.016 \\
0.018 \\
0.021 \\
0.029\end{array}$ & $\begin{array}{l}0.015 \\
0.013 \\
0.014 \\
0.019 \\
0.027\end{array}$ & $\begin{array}{l}0.017 \\
0.015 \\
0.015 \\
0.018 \\
0.027\end{array}$ & $\begin{array}{r}-6,300 \\
-14,000 \\
-10,000 \\
-6,600 \\
-1,800\end{array}$ & $\begin{array}{l}-- \\
-- \\
-- \\
-- \\
--\end{array}$ & $\begin{array}{l}-- \\
-- \\
-- \\
-- \\
--\end{array}$ \\
\hline $\begin{array}{l}286.5 \\
289.5 \\
292.6 \\
295.3 \\
298.7\end{array}$ & $\begin{array}{l}0.028 \\
0.018 \\
0.020 \\
0.021 \\
0.026\end{array}$ & $\begin{array}{l}0.025 \\
0.014 \\
0.024 \\
0.017 \\
0.023\end{array}$ & $\begin{array}{l}0.024 \\
0.016 \\
0.023 \\
0.021 \\
0.027\end{array}$ & $\begin{array}{l}-3,600 \\
-3,700 \\
-4,100 \\
-7,100 \\
-3,600\end{array}$ & $\begin{array}{l}-- \\
-- \\
-- \\
-- \\
--\end{array}$ & $\begin{array}{l}-- \\
-- \\
-- \\
-- \\
--\end{array}$ \\
\hline $\begin{array}{l}301.7 \\
304.8 \\
307.8 \\
310.9 \\
313.9\end{array}$ & $\begin{array}{l}0.028 \\
0.027 \\
0.027 \\
0.033 \\
0.029\end{array}$ & $\begin{array}{l}0.023 \\
0.024 \\
0.024 \\
0.032 \\
0.026\end{array}$ & $\begin{array}{l}0.026 \\
0.027 \\
0.026 \\
0.033 \\
0.028\end{array}$ & $\begin{array}{l}-3,400 \\
-3,200 \\
-8,100 \\
-1,800 \\
-4,100\end{array}$ & $\begin{array}{l}-- \\
-- \\
-- \\
-- \\
--\end{array}$ & $\begin{array}{l}-- \\
-- \\
-- \\
--\end{array}$ \\
\hline $\begin{array}{l}313.9 \\
317.0 \\
320.0 \\
323.1 \\
326.1\end{array}$ & $\begin{array}{l}-. \\
0.026 \\
0.020 \\
0.016 \\
0.019\end{array}$ & $\begin{array}{l}-- \\
0.024 \\
0.016 \\
0.012 \\
0.016\end{array}$ & $\begin{array}{c}-- \\
0.026 \\
0.018 \\
0.016 \\
0.018\end{array}$ & $\begin{array}{l}-3,700 \\
-4,500 \\
-6,600 \\
-8,900 \\
-5,400\end{array}$ & $\begin{array}{l}-- \\
-- \\
-- \\
--\end{array}$ & $\begin{array}{l}-- \\
-- \\
-- \\
-- \\
--\end{array}$ \\
\hline
\end{tabular}


Table 2.--Results of laboratory analyses for gravimetric water-content and water-potential measurements of drill-bit cuttings from

test hole USW UZ-6--Continued

\begin{tabular}{|c|c|c|c|c|c|c|}
\hline \multirow{2}{*}{$\begin{array}{l}\text { Depth } \\
\text { (meters) }\end{array}$} & \multicolumn{3}{|c|}{$\begin{array}{c}\text { Gravimetric water content } \\
\text { (gram per gram) }\end{array}$} & \multicolumn{3}{|c|}{$\begin{array}{l}\text { Water potential } \\
\text { (negative kilopascals) }\end{array}$} \\
\hline & Coarse & Fine & Composite & Coarse & Fine & Composite \\
\hline 329.2 & 0.025 & 0.020 & 0.022 & $-4,400$ & -- & -- \\
\hline 332.2 & 0.023 & 0.020 & 0.021 & $-4,700$ & -- & -- \\
\hline 335.3 & 0.011 & 0.011 & 0.010 & $-17,000$ & -- & -- \\
\hline 338.3 & 0.011 & 0.009 & 0.011 & $-22,000$ & -- & -- \\
\hline 341.4 & 0.022 & 0.019 & 0.020 & $-6,500$ & -- & -- \\
\hline 344.4 & 0.020 & 0.018 & 0.020 & $-5,800$ & -- & -- \\
\hline 347.5 & 0.010 & 0.009 & 0.010 & $-18,000$ & -- & -- \\
\hline 350.5 & 0.017 & 0.017 & 0.017 & $-9,900$ & -- & -- \\
\hline 353.6 & 0.016 & 0.015 & 0.018 & $-9,300$ & -- & -- \\
\hline 356.6 & 0.019 & 0.016 & 0.018 & $-5,700$ & -- & -- \\
\hline 359.6 & 0.005 & 0.004 & 0.005 & $-37,000$ & -- & -- \\
\hline 362.7 & 0.005 & 0.005 & 0.005 & $-29,000$ & -- & -- \\
\hline 365.7 & 0.003 & 0.003 & 0.003 & $-63,000$ & -- & -- \\
\hline 368.8 & 0.006 & 0.006 & 0.006 & -- & -- & -- \\
\hline 371.8 & 0.004 & 0.004 & 0.004 & $-24,000$ & -- & -- \\
\hline 374.9 & 0.012 & 0.010 & 0.011 & $-23,000$ & -- & -- \\
\hline 377.9 & 0.007 & 0.007 & 0.007 & $-36,000$ & -- & -- \\
\hline 381.0 & 0.004 & 0.004 & 0.003 & $-56,000$ & -- & -- \\
\hline 384.0 & 0.004 & 0.004 & 0.004 & $-38,000$ & -- & -- \\
\hline 387.1 & 0.006 & 0.006 & 0.006 & $-37,000$ & -- & -- \\
\hline 390.1 & 0.005 & 0.006 & 0.006 & $-42,000$ & - & -- \\
\hline 393.2 & 0.003 & 0.003 & 0.003 & $-47,000$ & -- & -- \\
\hline 396.2 & 0.004 & 0.004 & 0.003 & $-54,000$ & -- & -- \\
\hline 399.3 & 0.006 & 0.006 & 0.007 & -- & -- & -- \\
\hline 402.3 & 0.005 & 0.004 & 0.004 & -- & $-\infty$ & -- \\
\hline 405.4 & 0.004 & 0.005 & 0.004 & $-36,000$ & -- & -- \\
\hline 408.4 & 0.009 & 0.012 & 0.010 & $-38,000$ & -- & -- \\
\hline 411.5 & 0.009 & 0.017 & 0.016 & $-39,000$ & $-\infty$ & -- \\
\hline 414.5 & 0.010 & 0.019 & 0.018 & $-41,000$ & -- & -- \\
\hline 417.6 & 0.006 & 0.009 & 0.010 & $-46,000$ & -- & -- \\
\hline 420.6 & 0.011 & 0.015 & 0.014 & $-33,000$ & -- & -- \\
\hline 423.7 & 0.015 & 0.015 & 0.015 & $-50,000$ & -- & -- \\
\hline 426.1 & 0.011 & 0.014 & 0.014 & -- & $-26,000$ & -- \\
\hline 426.7 & 0.030 & 0.029 & 0.029 & -- & $-9,900$ & -- \\
\hline 429.7 & 0.032 & 0.036 & 0.038 & -- & $-3,300$ & -- \\
\hline
\end{tabular}


Table 2.--Results of laboratory analyses for gravimetric water-content and water-potential measurements of drill-bit cuttings from test hole USW UZ-6--Continued

\begin{tabular}{|c|c|c|c|c|c|c|}
\hline \multirow{2}{*}{$\begin{array}{l}\text { Depth } \\
\text { (meters) }\end{array}$} & \multicolumn{3}{|c|}{$\begin{array}{c}\text { Gravimetric water content } \\
\text { (gram per gram) }\end{array}$} & \multicolumn{3}{|c|}{$\begin{array}{c}\text { Water potential } \\
\text { (negative kilopascals) }\end{array}$} \\
\hline & Coarse & Fine & Composite & Coarse & Fine & Composite \\
\hline 432.8 & 0.023 & 0.026 & 0.027 & -- & $-7,400$ & -- \\
\hline 435.8 & 0.016 & 0.015 & 0.015 & -- & - & $-8,100$ \\
\hline 438.9 & 0.018 & 0.017 & 0.018 & - & -- & $-7,100$ \\
\hline 441.9 & 0.020 & 0.018 & 0.019 & -- & -- & $-4,100$ \\
\hline 445.0 & 0.024 & 0.022 & 0.024 & -- & -- & $-3,100$ \\
\hline 448.0 & 0.030 & 0.025 & 0.026 & -- & -- & $-1,800$ \\
\hline 451.1 & 0.028 & 0.029 & 0.030 & -- & -- & -420 \\
\hline 454.1 & 0.030 & 0.033 & 0.036 & -- & -- & -920 \\
\hline 457.2 & 0.046 & 0.050 & 0.046 & -- & -- & -450 \\
\hline 460.2 & 0.026 & 0.031 & 0.033 & -- & -- & $-1,000$ \\
\hline 463.3 & 0.025 & 0.037 & 0.038 & -- & -- & -460 \\
\hline 466.3 & 0.030 & 0.034 & 0.035 & - & -- & $-1,200$ \\
\hline 469.4 & 0.039 & 0.049 & 0.053 & -- & -- & -260 \\
\hline 472.4 & 0.040 & 0.052 & 0.053 & -700 & -- & -- \\
\hline 475.5 & 0.036 & 0.044 & 0.042 & -740 & -- & -- \\
\hline 478.5 & 0.032 & 0.037 & 0.038 & $-2,000$ & -- & -- \\
\hline 481.6 & 0.038 & 0.044 & 0.041 & $-2,400$ & -- & -- \\
\hline 484.6 & 0.022 & -- & 0.027 & $-5,600$ & -- & -- \\
\hline 487.7 & 0.019 & 0.027 & 0.026 & $-9,500$ & -- & -- \\
\hline 490.7 & 0.018 & 0.022 & 0.025 & $-9,500$ & -- & -- \\
\hline 493.8 & 0.011 & 0.014 & 0.014 & $-18,000$ & -- & -- \\
\hline 496.8 & 0.022 & 0.023 & 0.024 & $-4,700$ & -- & -- \\
\hline 499.8 & 0.016 & 0.018 & 0.019 & $-4,300$ & -- & -- \\
\hline 502.9 & 0.021 & 0.021 & 0.023 & $-3,600$ & -- & -- \\
\hline 505.9 & 0.021 & 0.023 & 0.024 & $-2,300$ & -- & -- \\
\hline 509.0 & 0.018 & 0.019 & 0.021 & $-3,300$ & -- & -- \\
\hline 512.0 & 0.021 & 0.022 & 0.022 & $-2,200$ & -- & -- \\
\hline 515.1 & 0.017 & 0.021 & 0.023 & $-2,500$ & -- & -- \\
\hline 518.1 & 0.017 & 0.017 & 0.019 & $-2,500$ & -- & -- \\
\hline 521.2 & 0.014 & 0.014 & 0.016 & $-3,700$ & -- & -- \\
\hline 524.2 & 0.015 & 0.015 & 0.017 & $-6,400$ & -- & -- \\
\hline 527.3 & 0.015 & 0.015 & 0.018 & $-3,800$ & -- & -- \\
\hline 530.3 & 0.014 & 0.013 & 0.015 & $-6,600$ & -- & -- \\
\hline 533.4 & 0.023 & 0.017 & 0.020 & $-2,400$ & -- & -- \\
\hline 536.4 & 0.023 & 0.026 & 0.027 & $-4,200$ & -- & -- \\
\hline
\end{tabular}


Table 2.--Results of laboratory analyses for gravimetric water-content and water-potential measurements of drill-bit cuttings from test hole USW UZ-6--Continued

\begin{tabular}{|c|c|c|c|c|c|c|}
\hline \multirow{2}{*}{$\begin{array}{l}\text { Depth } \\
\text { (meters) }\end{array}$} & \multicolumn{3}{|c|}{$\begin{array}{l}\text { Gravimetric water content } \\
\text { (gram per gram) }\end{array}$} & \multicolumn{3}{|c|}{$\begin{array}{l}\text { Water potential } \\
\text { (negative kilopascals) }\end{array}$} \\
\hline & Coarse & Fine & Composite & Coarse & Fine & Composite \\
\hline 539.5 & 0.025 & 0.024 & 0.022 & $-4,600$ & -- & -- \\
\hline 542.5 & 0.029 & 0.028 & 0.029 & $-3,100$ & -- & -- \\
\hline 545.6 & 0.035 & 0.033 & 0.037 & $-2,800$ & -- & -- \\
\hline 548.6 & 0.036 & 0.035 & 0.038 & $-2,800$ & -- & -- \\
\hline 551.7 & 0.037 & 0.054 & 0.049 & $-1,200$ & -- & -- \\
\hline 554.7 & 0.063 & 0.080 & 0.091 & $-1,000$ & -- & -- \\
\hline 557.8 & 0.036 & 0.046 & 0.053 & $-1,100$ & -- & -- \\
\hline 560.8 & 0.040 & 0.060 & 0.062 & $-3,600$ & -- & -- \\
\hline 563.9 & 0.042 & 0.075 & 0.077 & $-1,900$ & -- & -- \\
\hline 566.9 & 0.036 & 0.059 & 0.060 & $-3,000$ & -- & -- \\
\hline 569.9 & 0.052 & 0.073 & 0.073 & $-1,900$ & -- & -- \\
\hline 573.0 & 0.047 & 0.058 & 0.060 & $-3,200$ & -- & -- \\
\hline 575.1 & 0.048 & 0.055 & 0.053 & $-7,700$ & -- & -- \\
\hline
\end{tabular}

No comparison can be made between the gravimetric water content of coarse drill-bit cuttings and core samples because coring was not attempted in test hole UZ-6. Hammermeister and others (1985), however, have shown, using linear-regression analysis, that a good correlation exists between the watercontent values of coarse drill-bit cuttings and those of core samples. Only coarse drill-bit cuttings were used because they were determined to be more representative samples of in-situ hydrologic conditions.

The data for gravimetric water content in drill-bit cuttings from test hole UZ-6 (table 2) indicates generally less water content in the moderately and densely welded tuff and generally greater water content in the nonwelded and partially welded tuff. A graphic summary of results from test hole UZ-6 showing water-content measurements of coarse-, fine-, and composite-sized drill-bit cuttings related to the degree of welding as shown in figure 7.

A summary of the gravimetric water-content measurements and standard deviations of coarse drill-bit cuttings from the geologic units penetrated in test hole UZ-6 are listed in table 3 . The densely welded units have the smallest water-content values. The densely welded units of the Tiva Canyon Member and Topopah Spring Member of the Paintbrush Tuff have water-content values ranging from 0.003 to $0.077 \mathrm{~g} / \mathrm{g}$ with a composite average value of $0.021 \mathrm{~g} / \mathrm{g}$. The moderately welded unit of the Topopah Spring Member of the Paintbrush Tuff has water-content values ranging from 0.024 to $0.039 \mathrm{~g} / \mathrm{g}$ with an average value of $0.028 \mathrm{~g} / \mathrm{g}$. The partially to moderately welded units of the Tiva Canyon Member of the Paintbrush Tuff and the Prow Pass Member of the Crater Flat Tuff have water-content values ranging from 0.022 to $0.103 \mathrm{~g} / \mathrm{g}$ with a composite average value of $0.040 \mathrm{~g} / \mathrm{g}$. The nonwelded to partially 


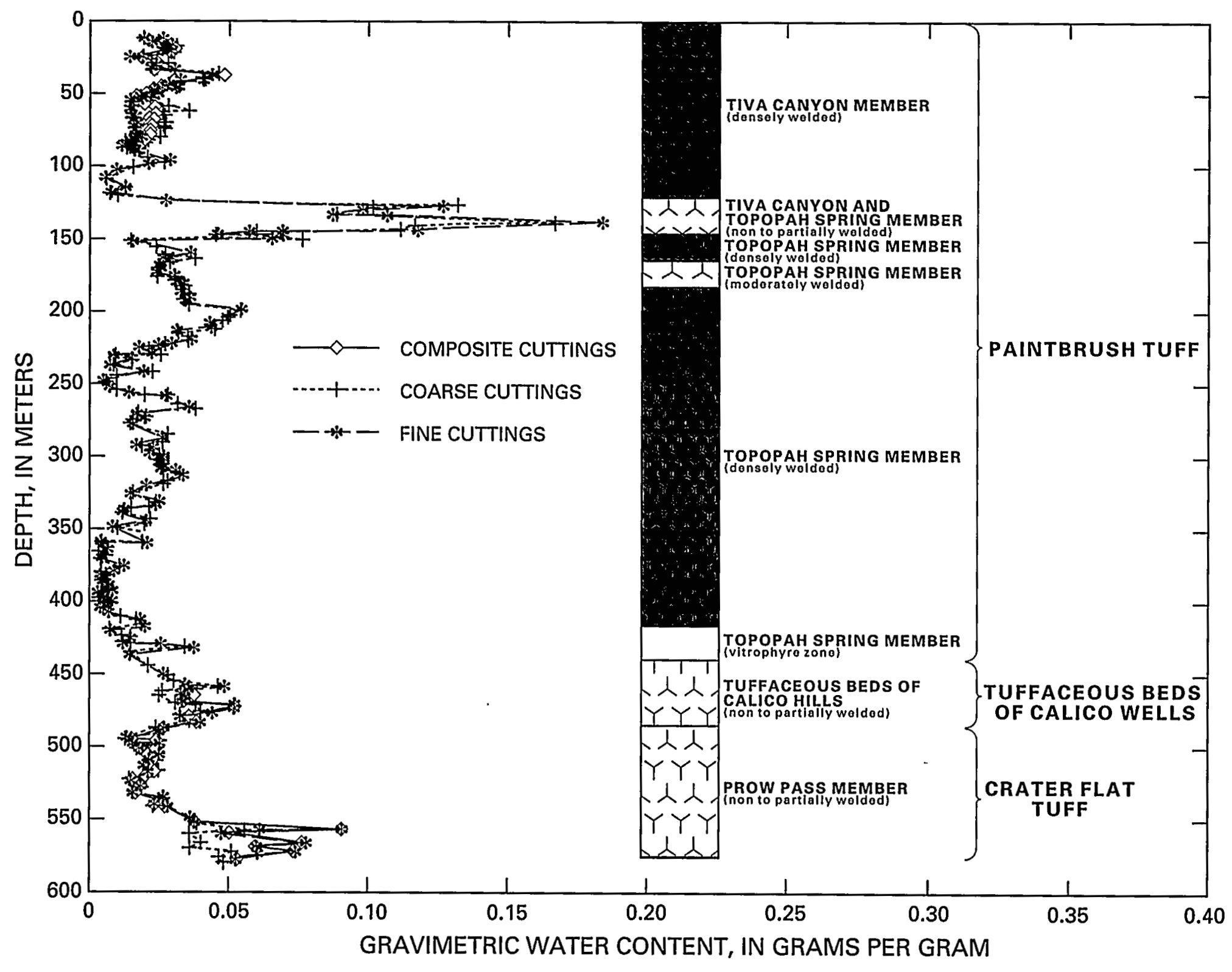

Figure 7.--Gravimetric water-content measurements of drill-bit cuttings from test hole USW UZ-6. 
Table 3.--Summary of gravimetric water-content measurements of drill-bit cuttings for test hole USW UZ-6, related to lithology and degree of welding

[All data values in gram per gram]

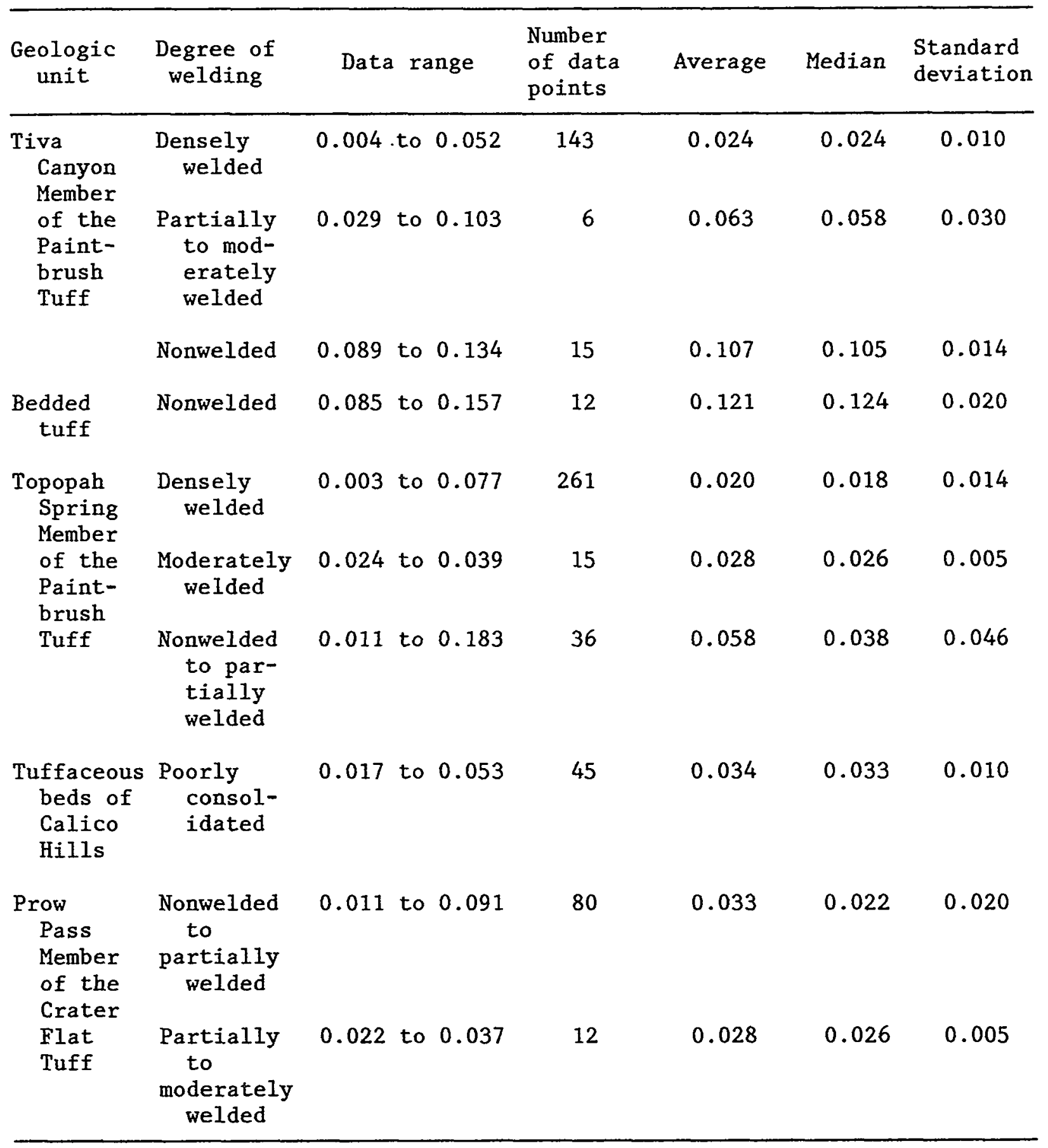


welded units of the Topopah Spring Member of the Paintbrush Tuff and the Prow Pass Member of the Crater Flat Tuff have water-content values ranging from 0.011 to $0.183 \mathrm{~g} / \mathrm{g}$ with a composite average value of $0.041 \mathrm{~g} / \mathrm{g}$. The nonwelded units have the largest water-content values. These units include the lowest part of the Tiva Canyon Member and the underlying unnamed bedded tuff at the top of the Topopah Spring Member of the Paintbrush Tuff. Water-content values range from 0.085 to $0.157 \mathrm{~g} / \mathrm{g}$ with a composite average value of $0.113 \mathrm{~g} / \mathrm{g}$. Lastly, the poorly consolidated tuffaceous beds of Calico Hills have watercontent values ranging from 0.017 to $0.053 \mathrm{~g} / \mathrm{g}$ with an average value of $0.034 \mathrm{~g} / \mathrm{g}$.

Average values of in-situ water content of drill-bit cuttings from test hole UZ-6, drilled with the vacuum reverse-air-circulation drilling method and those from test hole UZ-6s, drilled with the Odex $165 \mathrm{~T}$ drilling system, are only slightly different (table 4 ). Test hole UZ-6 had larger average values of gravimetric water content than did test hole UZ-6s for the Tiva Canyon Member and the bedded tuff of the Paintbrush Tuff. Test hole UZ- 6 had a smaller average value of gravimetric water-content for the Topopah Spring Member of the Paintbrush Tuff than did test hole UZ-6s, but only a few measurements were made on samples from test hole UZ-6s compared to those on samples from test hole UZ-6.

\section{Water-Potential Measurements}

Water potential is defined as the sum of matric and osmotic potentials. Water-potential measurements were made using a Richards SC-10 thermocouple psychrometer in conjunction with a NT-3 nanovoltmeter (Decagon Devices, Pullman, Wash.). The SC-10 thermocouple psychrometer is a stationary device with 10 rotating sample chambers. The Richards method (Richards and Ogata, 1958) was used to measure the water potential. This method is based on dipping a ceramic bead, attached at the thermocouple junction, into distilled water. The rate of evaporation of water from the ceramic bead during a period of as much as 10 minutes is measured as voltage-output readings on the nanovoltmeter while vapor equilibrium occurs. Voltage-output readings are recorded every minute.

Sample-chamber cups were placed within the 10 rotating sample chambers of the SC-10 thermocouple psychrometer. Three sample-chamber cups were filled with three of six calibration standards of known molality; six sample-chamber cups were filled with drill-bit cuttings; and the last sample-chamber cup was filled with distilled water. The calibration solutions were measured concurrently with the drill-bit cuttings to compensate for the zero drift of the nanovoltmeter amplifier due to changes in temperature. The calibration solutions were mixed using sodium chloride (NaCl) as the known salt. The approximate water potential of the calibration solutions in negativekilopascal equivalents were: $0.02 \mathrm{~m},-100 \mathrm{kPa} ; 0.05 \mathrm{~m},-230 \mathrm{kPa} ; 0.1 \mathrm{~m}$, $-460 \mathrm{kPa} ; 0.4 \mathrm{~m},-1,800 \mathrm{kPa} ; 0.8 \mathrm{~m},-3,700 \mathrm{kPa}$; and $1.5 \mathrm{~m},-7,100 \mathrm{kPa}$.

The same calibration solutions were not used for all drill-bit cuttings. As much as possible, samples of drill-bit cuttings with similar moisture contents, based on gravimetric water-content measurements, were measured together. Three of the six calibration solutions having approximate waterpotential values that would span the possible water-potential range of the six samples to be measured then were selected. 
Table 4.--Comparison of gravimetric water-content measurements of drill-bit cuttings from test holes USW UZ-6 and USW UZ-6s by geologic unit

[All data values in gram per gram]

\begin{tabular}{|c|c|c|c|c|c|c|c|c|c|c|c|}
\hline \multirow[b]{2}{*}{$\begin{array}{l}\text { Geologic } \\
\text { unit }\end{array}$} & \multicolumn{5}{|c|}{ Test hole USW UZ-6 } & \multicolumn{6}{|c|}{ Test hole USH UZ-6s } \\
\hline & Data range & $\begin{array}{l}\text { Number } \\
\text { of data } \\
\text { points }\end{array}$ & $\begin{array}{l}\text { Aver- } \\
\text { age }\end{array}$ & Median & $\begin{array}{l}\text { Standard } \\
\text { deviation }\end{array}$ & Data & range & $\begin{array}{l}\text { Number } \\
\text { of data } \\
\text { points }\end{array}$ & $\begin{array}{l}\text { Aver- } \\
\text { age }\end{array}$ & Median & $\begin{array}{l}\text { Standard } \\
\text { deviation }\end{array}$ \\
\hline $\begin{array}{l}\text { Tiva } \\
\text { Canyon } \\
\text { Hember } \\
\text { of the } \\
\text { Paint- } \\
\text { brush } \\
\text { Tuff }\end{array}$ & 0.004 to 0.134 & 164 & 0.033 & 0.026 & 0.027 & 0.005 & to 0.093 & 207 & 0.028 & 0.026 & 0.016 \\
\hline $\begin{array}{l}\text { Bedded } \\
\text { tuff }\end{array}$ & 0.085 to 0.157 & 12 & 0.121 & 0.124 & 0.020 & 0.007 & to 0.166 & 14 & 0.079 & 0.082 & 0.041 \\
\hline $\begin{array}{l}\text { Topopah } \\
\text { Spring } \\
\text { Member } \\
\text { of the } \\
\text { Paint- } \\
\text { brush } \\
\text { Tuff }\end{array}$ & 0.003 to 0.183 & 312 & 0.025 & 0.020 & 0.023 & 0.008 & to 0.092 & 17 & 0.034 & 0.025 & 0.029 \\
\hline
\end{tabular}

The sample-chamber cups were filled with drill-bit cuttings and calibration solutions in a humidified glove box to minimize evaporation. The SC-10 thermocouple psychrometer was allowed to equilibrate for a minimum of 30 minutes before any measurements were made. All measurements were made inside the humidified glove box.

The procedure for making water-potential measurements was begun by first making a temperature measurement. The sample chambers then were rotated and the ceramic bead of the thermocouple junction was wetted in the distilled water. The sample chambers then were rotated back to the appropriate chamber that would be measured first and as much as 10 minutes was allowed for vapor equilibrium to occur while voltage-output readings were recorded every minute. Another temperature measurement then was made. The ceramic bead was wetted again in the distilled water before making measurements of the next sample chamber. Thermocouple voltage outputs were measured in the following sequence: (1) calibration solutions from smallest to largest molality, (2) samples of drill-bit cuttings, and (3) calibration solutions from smallest to largest molality. The two voltage outputs for each calibration solution were averaged to compensate for any drift in temperature. The sample cups containing the drill-bit cuttings were carefully cleaned and dried after each set of measurements.

At the end of 10 minutes of recording voltage outputs, an averaged representative voltage-output reading was selected based on the evidence of a plateau. This plateau in voltage-output readings occurs when the system is in equilibrium--the humidity in the sample chamber remains constant, maintained by the constant evaporation of water from the thermocouple, and there is little change in the voltage-output readings. Once sufficient evaporation has occurred, the meniscus on the ceramic bead loses its cohesiveness, evaporation proceeds more quickly, and the voltage-output readings begin decreasing 
rapidly. For moister samples with a water potential of less than $-2,000 \mathrm{kPa}$, the plateau tended to be more evident during the last 5 minutes of voltageoutput readings and tended to last longer; the decrease from the plateau was usually not noted within the 10 minutes of voltage-output readings. For these moister samples with voltage-output readings of less than 20 microvolts on the nanovoltmeter, a difference of 0.10 microvolts or less between two consecutive readings generally was considered a sufficient plateau. For drier samples with a water potential of greater than $-5,000 \mathrm{kPa}$, the plateau tended to occur during the first 5 minutes of voltage-output readings and lasted for only a couple of minutes before the readings began decreasing rapidly. For samples with a water potential of greater than $-10,000 \mathrm{kPa}$, the plateau tended to occur before the voltage-output reading at 1 minute; therefore, the first voltage-output reading was considered to be the plateau.

The two voltage-output readings were averaged for each calibration solution as well as for the four recorded temperature values. The water potential then was calculated for each calibration solution based on the four averaged temperature values. The calculated water potential and the averaged voltageoutput readings of the calibration solutions were fit to a linear-regression equation. The results of the linear regression were used to construct the calibration curve. Using this calibration curve, the voltage-output reading from each sample of drill-bit cuttings is entered into the linear-regression equation, and the resulting value of the measured water potential of the sample is determined.

The degree of welding is related to the measurements of water potential-densely welded tuffs are the driest with the largest measurements of water potential; bedded and nonwelded tuffs are wetter with smaller measurements of water potential. Water-potential data of coarse- and fine-sized drill-bit cuttings as related to degree of welding are summarized in table 5 and presented graphically in figure 8 . The densely welded zones of the Topopah Spring Member of the Paintbrush Tuff from a depth of 147.4 to $158.5 \mathrm{~m}$ and from a depth of 174.0 to $420.6 \mathrm{~m}$ were the driest zones penetrated in test hole UZ- 6 , the water potential averaged $-16,000 \mathrm{kPa}$. The nonwelded to partially welded zone of the Topopah Spring Member of the Paintbrush Tuff from a depth of 126.5 to $132.1 \mathrm{~m}$ was slightly more moist; the water potential averaged $-12,000 \mathrm{kPa}$. Of the nonwelded zones, the unnamed bedded tuff from a depth of 132.1 to $137.7 \mathrm{~m}$ was the wettest with measurements of water potential averaging $-74 \mathrm{kPa}$. Another wet zone was the nonwelded part of the Tiva Canyon Member of the Paintbrush Tuff with an average water potential of $-270 \mathrm{kPa}$. At the bottom of the borehole in the Prow Pass Member of the Crater Flat Tuff, from a depth of 483.0 to $575.2 \mathrm{~m}$, the average value of water potential was $-4 ; 300 \mathrm{kPa}$. 
Table 5.--Summary of water-potential measurements of drill-bit cuttings for test hole USW UZ-6, related to lithology and degree of welding

[All data values in kilopascals]

\begin{tabular}{|c|c|c|c|c|c|c|c|}
\hline $\begin{array}{l}\text { Geologic } \\
\text { unit }\end{array}$ & $\begin{array}{l}\text { Degree of } \\
\text { welding }\end{array}$ & Data & range & $\begin{array}{l}\text { Number } \\
\text { of data } \\
\text { points }\end{array}$ & Average & Median & $\begin{array}{l}\text { Standard } \\
\text { deviation }\end{array}$ \\
\hline \multirow{3}{*}{$\begin{array}{l}\text { Tiva } \\
\text { Canyon } \\
\text { Member } \\
\text { of the } \\
\text { Paint- } \\
\text { brush } \\
\text { Tuff }\end{array}$} & $\begin{array}{l}\text { Densely } \\
\text { welded }\end{array}$ & -610 to & $-47,000$ & 47 & $-7,500$ & $-4,000$ & $-10,000$ \\
\hline & $\begin{array}{l}\text { Partially } \\
\text { to } \\
\text { moderately } \\
\text { welded }\end{array}$ & $-3,300$ to & $-13,000$ & 2 & $-8,200$ & $-8,200$ & $-6,900$ \\
\hline & Nonwelded & -28 to & -410 & 4 & -270 & -320 & -160 \\
\hline $\begin{array}{r}\text { Bedded } \\
\text { tuff }\end{array}$ & Nonwelded & -11 to & -160 & 3 & -74 & -52 & -77 \\
\hline \multirow{3}{*}{$\begin{array}{l}\text { Topopah } \\
\text { Spring } \\
\text { Member } \\
\text { of the } \\
\text { Paint- } \\
\text { brush } \\
\text { Tuff }\end{array}$} & $\begin{array}{l}\text { Densely } \\
\text { welded }\end{array}$ & -460 to & $-63,000$ & 87 & $-16,000$ & $-6,600$ & $-17,000$ \\
\hline & $\begin{array}{l}\text { Moderately } \\
\text { welded }\end{array}$ & -840 to & $-1,900$ & 5 & $-1,600$ & $-1,800$ & -430 \\
\hline & $\begin{array}{l}\text { Nonwelded } \\
\text { to } \\
\text { partially } \\
\text { welded }\end{array}$ & -220 to & $-50,000$ & 9 & $-12,000$ & $-7,400$ & $-14,000$ \\
\hline $\begin{array}{c}\text { Tuffaceous } \\
\text { beds of } \\
\text { Calico } \\
\text { Hills }\end{array}$ & $\begin{array}{l}\text { Poorly } \\
\text { consol- } \\
\text { idated }\end{array}$ & -260 to & $0-7,100$ & 15 & $-1,800$ & $-1,000$ & $-1,800$ \\
\hline \multirow{2}{*}{$\begin{array}{l}\text { Prow } \\
\text { Pass } \\
\text { Member } \\
\text { of the } \\
\text { Crater } \\
\text { Flat } \\
\text { Tuff }\end{array}$} & $\begin{array}{l}\text { Nonwelded } \\
\text { to } \\
\text { partially } \\
\text { welded }\end{array}$ & $-1,000$ to & o $-18,000$ & 27 & $-4,400$ & $-3,300$ & $-1,900$ \\
\hline & $\begin{array}{l}\text { Partially } \\
\text { to } \\
\text { moderately } \\
\text { welded }\end{array}$ & $-2,800$ to & $0-4,600$ & 4 & $-3,700$ & $-3,600$ & -860 \\
\hline
\end{tabular}




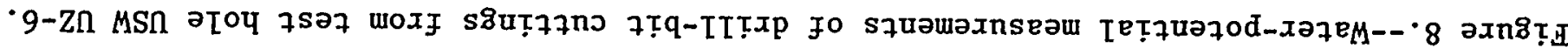

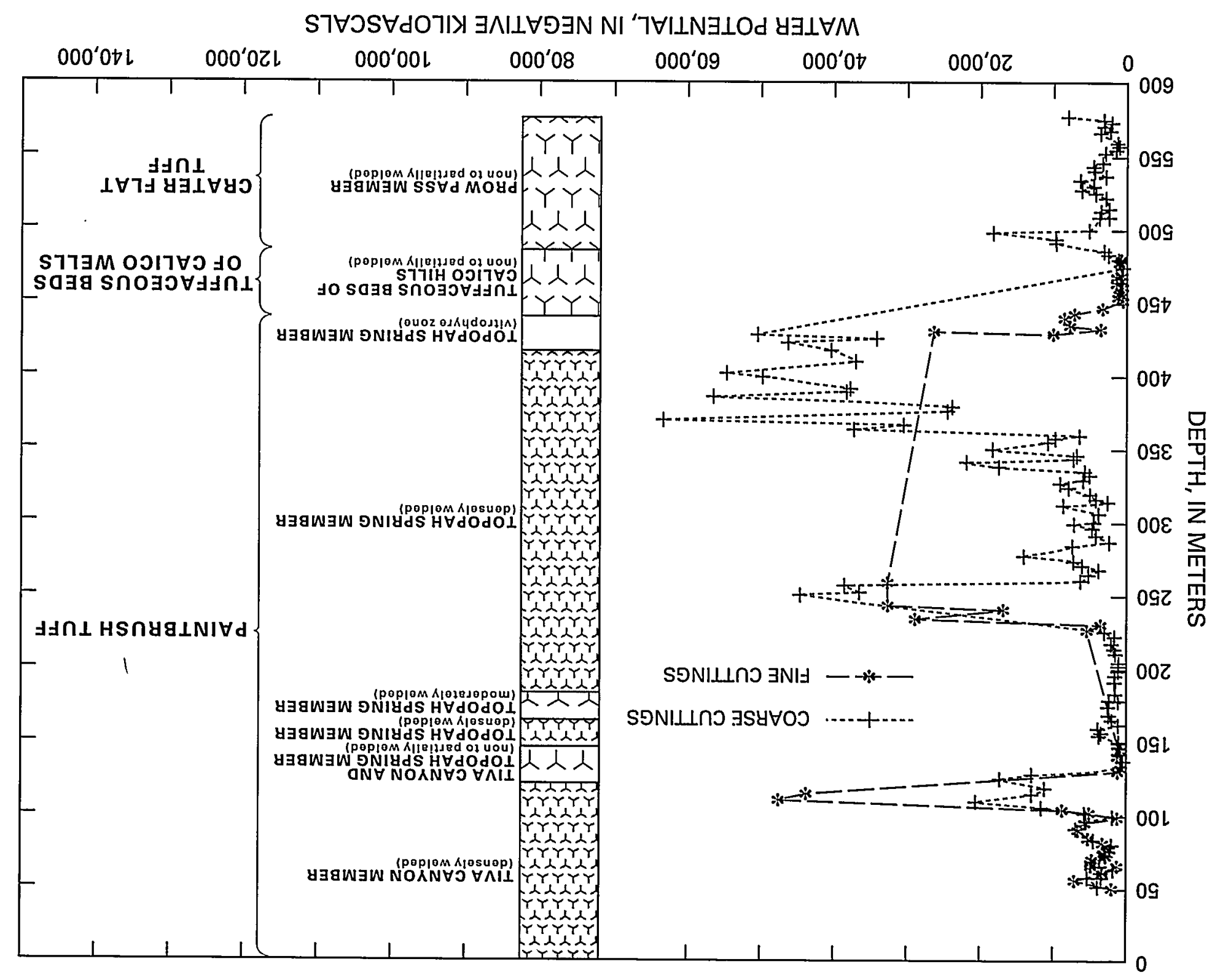




\section{Geophysical Logs and Television Videotapes}

A suite of borehole geophysical logs were obtained in test hole UZ-6 during and after the completion of drilling. These logs were used to determine: (1) formation lithology; (2) borehole size and deviation; (3) fracture location; (4) formation porosity; and (5) moisture content. A summary of the logs obtained and the depth interval for which each of these logs is available are provided in table 6. A downhole television camera used to monitor borehole conditions, such as caving or bridging, was lowered into test hole UZ-6 on eight separate occasions before the total depth of $575.2 \mathrm{~m}$ was drilled. One inspection of the borehole was made when the drill pipe parted at a depth of $241.1 \mathrm{~m}$, making it necessary to determine the position of the parted drill pipe in the borehole so that a fishing tool could be designed to retrieve the drill pipe. A television camera run was made after reaching the maximum drilled depth of $575.2 \mathrm{~m}$, but due to caving, the maximum depth reached by the camera was only $565.4 \mathrm{~m}$. A black and white videotape of this inspection is available from a depth of $565.4 \mathrm{~m}$ to the land surface. Several months after initial logging, two separate downhole television-camera inspections were made for which color videotapes are available. These inspections were made primarily to visually observe fracture frequency (fig. 9), fracture orientation, borehole enlargement, lithologic changes, and moist zones. The three downhole television-camera inspections for which videotapes are available are listed at the end of table 6 . 
Table 6.--Sumary of geophysical logs and television videotapes obtained in test hole USW UZ-6

\begin{tabular}{|c|c|c|c|c|}
\hline \multirow[b]{2}{*}{ Log type } & \multirow[b]{2}{*}{ Log date } & \multirow[b]{2}{*}{$\begin{array}{l}\text { Logging } \\
\text { company }\end{array}$} & \multicolumn{2}{|c|}{ Logged interval } \\
\hline & & & $\begin{array}{l}\text { Bottom } \\
\text { of log } \\
\text { (meters) }\end{array}$ & $\begin{array}{c}\text { Top of } \\
\text { log } \\
\text { (meters) }\end{array}$ \\
\hline Caliper & $08 / 07 / 84$ & Birdwell & 233 & 82.3 \\
\hline Caliper & $08 / 31 / 84$ & Birdwe11 & 369 & 82.3 \\
\hline Caliper & $09 / 26 / 84$ & Birdwell & 563 & 82.3 \\
\hline Density & $08 / 07 / 84$ & Birdwell & 235 & 91.4 \\
\hline Densilog Gamma Ray $(12.7 \mathrm{~cm})$ & $09 / 28 / 84$ & $\begin{array}{l}\text { Dresser } \\
\text { Atlas }\end{array}$ & 566 & 99.1 \\
\hline Densilog Gamma Ray $(5.1 \mathrm{~cm})$ & $09 / 28 / 84$ & $\begin{array}{r}\text { Dresser } \\
\text { Atlas }\end{array}$ & 566 & 99.1 \\
\hline Compensated densilog & $09 / 28 / 84$ & $\begin{array}{l}\text { Dresser } \\
\text { Atlas }\end{array}$ & 566 & 98.8 \\
\hline $\begin{array}{l}\text { Fluid density for water } \\
\text { location }\end{array}$ & $09 / 26 / 84$ & Birdwell & 568 & 544 \\
\hline Gamma Ray & $08 / 07 / 84$ & Birdwell & 234 & 0 \\
\hline Gamma Ray & $09 / 28 / 84$ & Birdwell & 564 & 0 \\
\hline Spectralog Gamma Ray $(12.7 \mathrm{~cm})$ & $09 / 28 / 84$ & $\begin{array}{l}\text { Dresser } \\
\text { Atlas }\end{array}$ & 566 & 0 \\
\hline Spectralog Gamma Ray $(5.1 \mathrm{~cm})$ & $09 / 28 / 84$ & $\begin{array}{r}\text { Dresser } \\
\text { Atlas }\end{array}$ & 566 & 0 \\
\hline Spectralog & $09 / 28 / 84$ & $\begin{array}{l}\text { Dresser } \\
\text { Atlas }\end{array}$ & 566 & 0 \\
\hline Epithermal neutron porosity & $08 / 07 / 84$ & Birdwel1 & 234 & 91.4 \\
\hline Epithermal neutron porosity & $09 / 28 / 84$ & Birdwell & 564 & 91.4 \\
\hline $\begin{array}{l}\text { Induction } \\
\text { Induction }\end{array}$ & $\begin{array}{l}08 / 07 / 84 \\
09 / 26 / 84\end{array}$ & Birdwell & 233 & 91.4 \\
\hline Dielectric $\log (12.7 \mathrm{~cm})$ & $\begin{array}{l}09 / 26 / 84 \\
09 / 28 / 84\end{array}$ & $\begin{array}{c}\text { Birdwell } \\
\text { Dresser } \\
\text { Atlas }\end{array}$ & $\begin{array}{l}564 \\
564\end{array}$ & $\begin{array}{l}81.8 \\
99.1\end{array}$ \\
\hline Temperature & $08 / 07 / 84$ & Birdwell & 234 & 0 \\
\hline Temperature & $09 / 28 / 84$ & Birdwell & 564 & 0 \\
\hline Geophone Survey (SVC) & $10 / 04 / 84$ & Birdwel1 & 561 & 102 \\
\hline $\begin{array}{l}\text { Black and white } \\
\text { television videotape }\end{array}$ & $09 / 24 / 84$ & Westech & 565.4 & 0 \\
\hline $\begin{array}{l}\text { Color television videotape } \\
\text { Color television videotape }\end{array}$ & $\begin{array}{l}11 / 13 / 84 \\
01 / 16 / 85\end{array}$ & $\begin{array}{l}\text { Westech } \\
\text { Westech }\end{array}$ & $\begin{array}{l}563.9 \\
564.2\end{array}$ & $\begin{array}{l}98.8 \\
98.8\end{array}$ \\
\hline
\end{tabular}




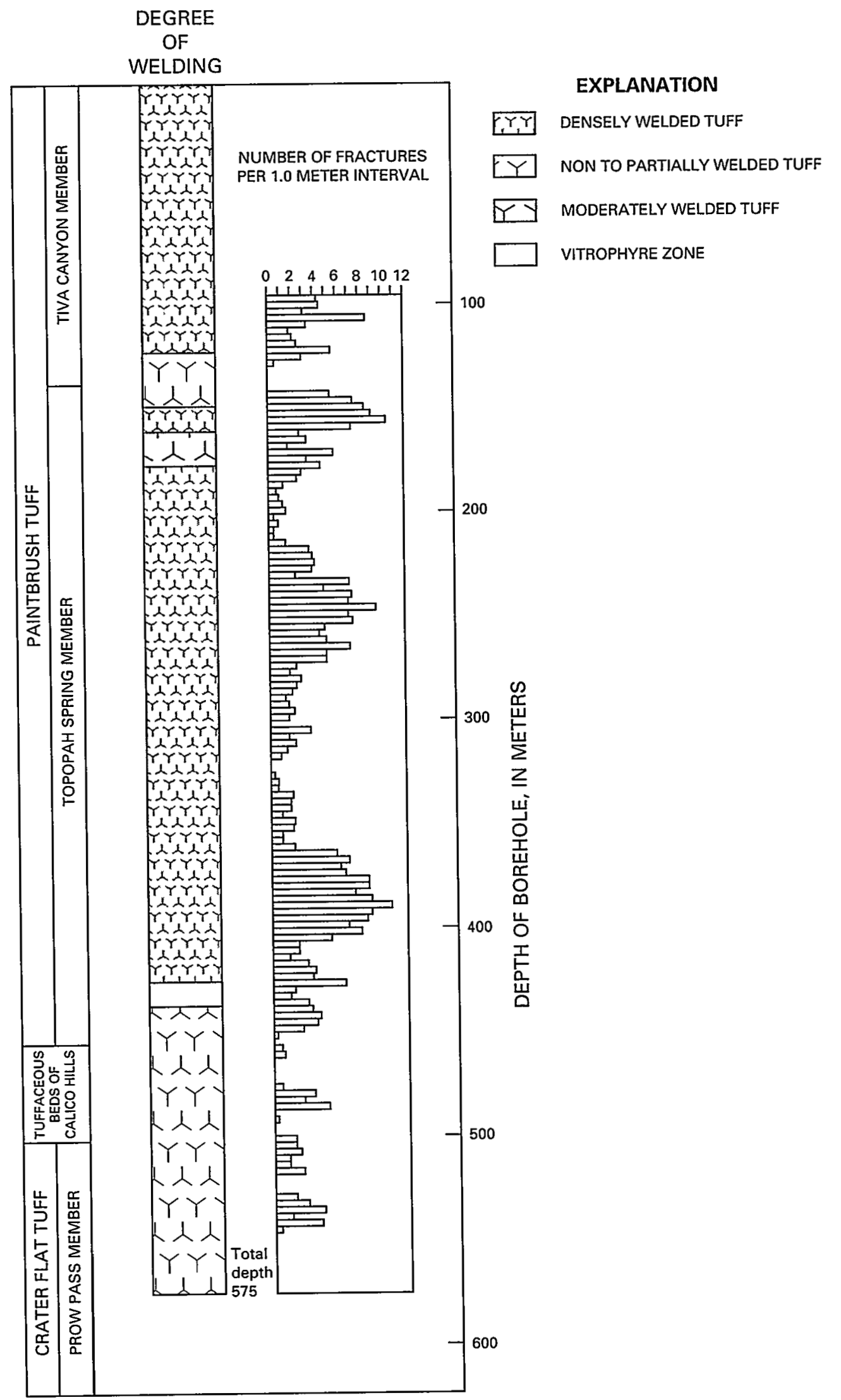

Figure 9.--Vertical distribution and number of fractures in test hole USW UZ-6. 


\section{SUMMARY}

This report presents borehole and geohydrologic data for test hole UZ-6, a deep $(575.2 \mathrm{~m})$ unsaturated-zone test hole drilled into tuff using the vacuum reverse-air-circulation method of dry drilling. No coring was done during the drilling of test hole UZ-6. The geologic units penetrated were the Tiva Canyon Member of the Paintbrush Tuff, an unnamed bedded tuff, the Topopah Spring Member of the Paintbrush Tuff, the tuffaceous beds of Calico Hills, and the Prow Pass Member of the Crater Flat Tuff.

Geohydrologic data include the lithology of geologic units penetrated, measurements of gravimetric water content, and measurements of water potential for coarse-, fine-, and composite-sized drill-bit cuttings. The data indicate that moisture within the geologic units is related to lithology, primarily the degree of welding. The densely welded units of the Tiva Canyon Member and the Topopah Spring Member of the Paintbrush Tuff have the smallest values of gravimetric water content, whereas the nonwelded units of the Tiva Canyon Member of the Paintbrush Tuff and the unnamed bedded tuff at the top of the Topopah Spring Member of the Paintbrush Tuff have the largest values. The densely welded unit and the partially to nonwelded unit of the Topopah Spring Member of the Paintbrush Tuff have the most negative water potential values; the nonwelded unit of the Tiva Canyon Member and the nonwelded unnamed bedded tuff of the Paintbrush Tuff have the least negative water-potential values.

\section{REFERENCES CITED}

Gardner, W.H., 1965, Water content, in Black, C.A., ed., Methods of soil analyses--Part 1, Physical and mineralogical properties, including statistics of measurement and sampling: Madison, Wis., American Society of Agronomy, Agronomy Monograph 9, p. 82-127. (NNA.900208.0007)

Hammermeister, D.P., Blout, D.0., and McDaniel, J.C., 1985, Drilling and coring methods that minimize the disturbance of cuttings, core, and rock formations in the unsaturated zone, Yucca Mountain, Nevada, in Proceedings of the National Water Well Association Conference on Characterization and Monitoring of the Vadose (Unsaturated) Zone, Denver, 1985: Worthington, Ohio, National Water Well Association, p. 507-541. (HQS.880517.2696)

Montazer, Parviz, and Wilson, W.E., 1984, Conceptual hydrologic model of flow in the unsaturated zone, Yucca Mountain, Nevada: U.S. Geological Survey Water-Resources Investigations Report 84-4345, 55 p. (NNA.870519.0109)

Richards, L.A., and Ogata, G., 1958, Thermocouple for vapor pressure measurement on biological and soil systems at high humidity: Science, v. 128, p. 1089-1090. (HQS.880517.2837)

Roseboom, E.H., Jr., 1983, Disposal of high-level nuclear waste above the water table in arid regions: U.S. Geological Survey Circular 903, 21 p. (NNA. 870824.0061)

Squires, R.R., and Young, R.L., 1984, Flood potential of Fortymile Wash and its principal southwestern tributaries, Nevada Test Site, southern Nevada: U.S. Geological Survey Water-Resources Investigations Report $83-4001,33$ p. (NNA.890511.0110) 
Waddell, R.K., 1982, Two-dimensional, steady-state model of ground-water flow, Nevada Test Site and vicinity, Nevada-California: U.S. Geological Survey Water-Resources Investigations Report 82-4085, 72 p. (NNA870518.0055)

Waddell, R.K., Robison, J.H., and Blankennagel, R.K., 1984, Hydrology of Yucca Mountain and vicinity, Nevada-California--Investigative results through mid-1983: U.S. Geological Survey Water-Resources Investigations Report $84-4267,72 \mathrm{p}$. (NNA.870406.0343)

Whitfield, M.S., 1985, Vacuum drilling of unsaturated tuffs at a potential radioactive-waste repository, Yucca Mountain, Nevada, in Proceedings of the National Water Well Association Conference on Characterization and Monitoring of the Vadose (Unsaturated) Zone, Denver, Colo., 1985: Worthington, Ohio, National Water Well Association, p. 413-423. (NNA. 870407.0327)

Whitfield, M.S., Thordarson, William, Hammermeister, D.P., 1990, Drilling and geohydrologic data for test hole USW UZ-1, Yucca Mountain, Nye County, Nevada: U.S. Geological Survey Open-File Report 90-354, 39 p. (NNA.900622.0450)

NOTE: Numbers in parentheses following each cited reference are for Office of Civilian Radioactive Waste Management Records Management purposes only and should not be used when ordering the publication.

The following number is for Office of Civilian Radioactive Waste Management Records Management puxposes only and should not be used when ordering this publication: NNA.920123.0088 